\title{
Spatial and temporal variations in food web structure from newly-opened habitat at hydrothermal vents
}

\author{
Sylvie Marylène Gaudron ${ }^{a, *}$, Sébastien Lefebvre ${ }^{b}$, Amandine Nunes Jorge $^{a, c}$, Françoise Gaill ${ }^{a, d}$, \\ Florence Pradillon ${ }^{\mathrm{a}, \mathrm{e}}$
}

\author{
a Université Pierre et Marie Curie, Bâtiment A 4ème étage pièce 415, Paris VI, CNRS, UMR7138, Systématique, \\ Adaptation, Evolution, équipe AMEX, 7 quai St Bernard, 75252 Paris cedex 05, France \\ b Université de Lille1 Sciences et Technologies, UMR CNRS 8187 LOG « Laboratoire d'Océanologie et \\ Géosciences $\gg$, Station marine de Wimereux, 28 av. Foch, 62930 Wimereux, France \\ ${ }^{c}$ Max Planck Institute for Marine Microbiology, Celsiusstrasse 1, 28359 Bremen, Germany \\ ${ }^{d}$ CNRS, INEE, 3 rue Michel Ange, 75017 Paris, France \\ e IFREMER, Centre de Brest, Département des Ressources physiques et Ecosystèmes de fond de mer, BP 70, \\ 29280 Plouzané, France
}

\footnotetext{
*: Corresponding author : Sylvie Marylène Gaudron, Tel.: +33 (0) 144273781 ; fax: +33 (0) 144272145 ; email address : sylvie.gaudron@snv.jussieu.fr
}

\begin{abstract}
:
To highlight the spatio-temporal variability of the food web structure of hydrothermal vent fauna from newly-opened habitat, a series of Titanium Ring for Alvinellid Colonization devices (TRACs) was deployed at TICA site on the East Pacific Rise in 2006. This experiment was conducted for periods of 4 days, 13 days and one month and deployments were aligned along a gradient from the basaltic bottom to the vent openings. d13C values of colonists revealed a narrower range of carbon sources in proximity to vent openings in Alvinella pompejana habitat than in Tevnia jerichonana habitat, separated by a distance of four meters. This was possibly due to a spatial change in available food sources with a possible higher contribution of particulate organic matter (POM) to the siboglinid habitat compared to a higher contribution of microbial primary producers such as Epsilonproteobacteria in the alvinellid habitat. Temporal variability was also observed during experimentation in the form of a shift in either $\mathrm{d} 13 \mathrm{C}$ and/or d15N values for A. pompejana, Lepetodrilus elevatus, dirivultid copepods and polynoid polychaetes within a one-month window showing first of all, fast tissues turnover and secondly, a possible switch in feeding strategy or food sources. Lepidonotopodium riftense and Branchinotogluma sandersi may have to alternate between detritivorous and predatory feeding strategies. In addition, through the analysis of stable isotope composition of A. pompejana and its episymbionts, we provided evidence that these attached bacteria formed part of the worms' diet during the course of these colonization experiments.
\end{abstract}

\section{Highlights}

We analyzed the food web structure of vent fauna within colonization experiments. We demonstrated the small spatial and small temporal variability of the food web structure. We demonstrated the switch of feeding strategies for some metazoans. We demonstrated the change of food sources for nutritional strategy of some metazoans. Episymbionts of Alvinella pompejana may be part of their diet.

Keywords: Trophic relationships ; Food web structure ; Hydrothermal vent ; East Pacific Rise ; Stable isotopes ; Colonization experiment ; TRACs ; Alvinella pompejana ; Epibiosis 


\section{INTRODUCTION}

Hydrothermal vents are ecosystems where primary producers are chemolithoautotrophic microorganisms that take advantage of the mixing interface between seawater and vent fluids. These microbes fix inorganic carbon through the oxidation of reduced compounds, into organic carbon, at the base of the food web (Jannasch, 1985; Karl, 1995; Childress and Fisher, 1992). In contrast to the paucity of conspicuous life forms in the deep ocean, hydrothermal vents harbor a flourishing biomass of megafauna where one or two species are visually dominant. Depending on vent geographic location and local environmental factors, these dominant species may belong to polychaete tubeworms, bathymodiolid mussels, vesicomyid clams, alvinocarid shrimps, and/or provannid gastropods. Many of them are foundation species that create habitat or modify the local density and diversity of macrofaunal invertebrates (Govenar, 2010). Foundation species also often harbor chemoautotrophic symbiotic bacteria that are their primary source of nutrition. Hydrothermal vents are very unstable in terms of abiotic factors such as the chemical composition of the emitted fluid (sulfide, methane or hydrogen) and temperature (Luther et al., 2001; Le Bris et al., 2006). The spatial and temporal variability of abiotic factors not only dictates the structure of metazoan communities (Tunnicliffe, 1991; Sarrazin et al., 1999; Cuvelier et al., 2009) but also has an indirect impact on carbon fluxes within the hydrothermal vent food web (Limén et al., 2007; De Busserolles et al., 2009; Govenar, 2012). Deep-sea hydrothermal vents are similar to intertidal zones in terms of habitat heterogeneity, where patchiness of animal communities may occur at the decimeter scale (Levesque et al., 2006; Dubois et al., 2007). They typically display faunal zonation along environmental gradients related to the distance from vent openings (Sarrazin and Juniper, 1999; Limén et al., 2007). The metazoan species Alvinella pompejana lives in closer proximity to vent openings being both more thermotolerant and adapted to high environmental sulfide concentrations (Le Bris and Gaill, 2007), when compared to species further away from the vent openings such as Riftia pachyptila (Tunnicliffe, 1991; Van Dover, 2000; Nees et al., 2009). 
Several food sources are at the base of the food web of hydrothermal vents. A percentage of particulate organic matter (POM) is known to contribute to the diets of non-symbiotic hydrothermal vent fauna (Levesque et al., 2005, 2006; Limén et al., 2007). It is composed of endogenous sources including a mixture of detritus from decaying bodies, mucus and heterotrophic microbial cells and exogenous sources such as small fractions of photosynthetically-derived surface material (diatoms and coccolithophorids) and associated bacteria (Levesque et al., 2005). At Juan de Fuca Ridge, in the Northeast Pacific, stable carbon isotopic composition $\left(\delta^{13} \mathrm{C}\right)$ of POM vary at the scale of a single sulfide edifice, which reflects an increasing proportion of exogenous sources of organic matter with increasing distance from the vent fluid emission (Limén et al., 2007). Other significant sources of organic matter are provided by free-living microbes and symbiotic bacteria (Bergquist et al., 2007; Govenar, 2012). For instance, Epsilonproteobacteria (free-living microbes) are considered to be key players in the cycling of carbon, nitrogen and sulfur at hydrothermal vents on the East Pacific Rise (EPR) (Campbell et al., 2006; Sievert et al., 2009; Sievert and Vetriani, 2012). As a consequence of the variability in available food sources at increasing distance from fluid emissions at the scale of a single vent sulfide edifice, food web structures may also display significant differences at similar spatial scale. Despite a number of studies attempting to decipher trophic relationships at hydrothermal vents using the stable isotope technique (e.g. Van Dover and Fry, 1989; Van Dover and Fry, 1994; Fisher et al., 1994; Vereshchaka et al., 2000; Colaço et al., 2002; Levesque et al., 2003, 2006; Limén et al., 2007; Debusserolles et al., 2009), complex feeding relationships among a single entire animal community retrieved with a "bushmaster" sampling device were only recently elucidated at a diffuse flow site of Juan de Fuca Ridge in the Northeast Pacific (Bergquist et al., 2007). Levesque et al. (2006) simultaneously studied temporal and spatial trends in stable isotope compositions of 10 representative invertebrates' species and revealed that species stable isotopic ratios and food web structures were constrained by the faunal community structure over yearly time scales and tens of meters to kilometers spatial scales. On a much finer scale (decimeters), Limén et 
al. (2007) and De Busserolles et al. (2009) evidenced the influence of local environmental conditions that may shape small scale variations of the food sources, of the faunal stable isotopic ratios and of the food web structure.

In situ colonization experiments have been carried out for over two decades at hydrothermal vents using polycarbonate plates, basalt rocks, sponges or titanium rings (Van Dover et al., 1988; Shank et al., 1998; Taylor et al., 1999; Mullineaux et al., 1998, 2003; Pradillon et al., 2005, 2009; Kelly et al., 2007; Kelly and Metaxas, 2008). Titanium Ring for Alvinellid Colonization (TRACs) deployed near vent openings at hydrothermal vents in the Pacific (East Pacific Rise $9^{\circ} \mathrm{N}$ and $13^{\circ} \mathrm{N}$ ) demonstrated that the alvinellid polychaete Alvinella pompejana was a pioneer metazoan species among assemblages that colonized TRACs on smoker sulfide edifices, after the initial colonization of filamentous bacteria (Taylor et al., 1999; Alain et al., 2004; Pradillon et al., 2005, 2009).

Alvinellid worms secrete tubes or mucus on the surfaces they colonize, and may locally modify flow patterns, fluid emission, mineral precipitation and the degree of hydrothermal mixing with seawater, allowing establishment of other species exhibiting a lower tolerance to severe hydrothermal conditions (Juniper et al., 1992; Juniper and Martineu, 1995; Sarrazin and Juniper, 1999; Zbinden et al., 2003; Le Bris et al., 2005; Pradillon et al., 2009). Colonization of new active hydrothermal edifices by metazoan species generally mostly occurs through larval dispersal and recruitment (Lutz et al., 1984). However, newly-available surfaces in TRAC experiments deployed by Pradillon et al. (2005) over variable time intervals between 1995 and 1999 at EPR $9^{\circ} 50^{\prime} \mathrm{N}$ and $13^{\circ} \mathrm{N}$ were mainly colonized by post-larval stages, juveniles and adults. The occurrence of large sized A. pompejana on TRACs deployed for only a few days suggested that those individuals migrated by secreting new tubes from adjacent parts of the sulfide edifice, rather than recruiting as larvae. Pradillon et al. (2009) showed that following TRAC deployments on active sulfide edifices, complex structure made of mineral precipitation and alvinellid tubes quickly form and tend to buffer the sharp centimeter scale temperature gradients, thus allowing the development of a more diverse faunal communities within a 
121 few days. The authors proposed that the slight differences observed in the community structures of

122 assemblages retrieved from different TRACs reflected local environmental conditions. Trophic

123 relationships and resources partitioning may also significantly affect the development of these

124 assemblages, but they were not investigated in that study.

125 Here, we are looking at the variability of the food web structure in the early steps of faunal

126 assemblage formation using stable isotope analyses in order to highlight the possible small spatial

127 scale (few meters) and temporal scale (few days to a month) variability of samples collected on and

128 around hydrothermal vent edifices. We conducted new in situ colonization experiments by deploying

1293 successive series of TRACs along a spatial gradient from a vent opening at the EPR $9^{\circ} 50^{`} \mathrm{~N}$.

130 Closest to the vent opening, were TRACs deployed among alvinellids, where we expected the quick

131 formation of a complex mineral-tube structure accompanied by the development of the faunal

132 assemblage. The two other habitats selected were at the basis of Tevnia jerichonana tubeworms, and

133 on bare basaltic seafloor within a few meters from the alvinellid deployment. In the sibloglinid

134 habitat, although rather high temperature might be expected, the quick formation of a mineral-tube

135 matrix is not expected, which may result in a completely different faunal assemblages development,

136 perhaps much slower. Experiments were conducted for three periods: 4 days, 13 days and one

137 month. The questions to be addressed in this paper are: 1) Are the stable isotopic compositions of

138 some target non-symbiotic invertebrates recovered from colonization experiments from different

139 habitats on a vent variable with deployment duration (4d, 13d and 29-33d)? 2) Do food web

140 structures at vents vary with space and time? 3) Is Alvinella pompejana able to feed on its

141 episymbiotic bacteria in experimental conditions?

142

1432 MATERIAL AND METHODS

$144 \quad 2.1$ Study site, TRACs and fauna 
Our study site (Fig.1) was a basalt hosted vent system at $9^{\circ} 50^{\prime} \mathrm{N}$ on the East Pacific Rise

146 (EPR), where a volcanic eruption occurred in winter 2005-2006, which covered many of the

147 previously established vent animal communities (Soule et al., 2007; Bennet et al., 2011). In this

148 study, colonization experiments were carried out a few months after the eruption. At that time,

149 animal communities were re-establishing themselves around new vigorous vents and large

150 aggregates of symbiotic Tevnia jerichonana tubeworms, up to $30 \mathrm{~cm}$ long (Nees et al., 2009) as well

151 as alvinellid polychaetes colonies were observed. Series of three colonization devices (TRACs for

152 Titanium Ring for Alvinellid Colonization) were deployed on each occasion for incremental time

153 periods (4 days, 13 days and 29-33 days) between November and December 2006 (Table 1) during

154 the two oceanographic cruises LADDER 1 and 2 at two active sites (Fig.1). For each series

155 (representing one deployment interval), three deployment locations were selected: one on alvinellid

156 colonies, one near T. jerichonana tubeworms, and one on the bare basalt out of venting influence.

157 Eight TRAC deployments (Fig.2; Table 1) were carried out at the TICA site (950'24'’N,

$\left.158104^{\circ} 17^{\prime} 30^{\prime \prime} \mathrm{W}\right)$, where active venting occurred along the eastern wall of the axial graben. Exposed

159 surfaces of basalts in vigorous diffuse flows were densely colonized by $T$. jerichonana siboglinid

160 tubeworms, and were adjacent to sulfide flanges with more focused hot fluid emissions and

161 assemblage of alvinellids. Two TRACs were deployed on the sulfide flanges covered by alvinellids

162 for 4 and 13 days, three TRACs were deployed at the base of T. jerichonana siboglinid tubeworms

163 for 4, 13 and 29 days, and three TRACs were deployed a few meters away, on fresh basalts for 4, 13

164 and 29 days (Fig.2; Table 1). Due to dive logistics constraints, our one-month TRAC deployment on

165 alvinellids was not at the TICA site but in a similar environment at the Bio_9 site (9॰50'18' 'N,

$166104^{\circ} 17^{\prime} 32^{\prime \prime} \mathrm{W}$ ) (Fig. 1; Table 1). Bio_9 was a large black smoker complex of more than 20 spires

167 hosting alvinellid polychaetes located about $150 \mathrm{~m}$ from the TICA site (Fig.1). Temperature was

168 measured before deployment of each TRAC, and areas with temperatures below $20^{\circ} \mathrm{C}$ were selected.

169 The TRACs $(15 \mathrm{~cm}$ in diameter and $10 \mathrm{~cm}$ in height $)$ were hollow cylinders that mimicked a newly- 
170 opened surface when deployed on an active hydrothermal edifice. They had holes in their sides to

171 enable circulation of vent fluids and contained internal spokes to enable anchoring of alvinellid tubes

172 and associated fauna (Pradillon et al., 2005, 2009). Each TRAC was equipped with MICREL

173 autonomous probes that semi-continuously recorded the temperature inside the device during the in

174 situ deployment (Table 1). Deployment and recovery of TRACs were performed by the manned

175 submersible Alvin (Woods Hole Oceanographic Institution, USA) (Table 1). At recovery, devices

176 were placed in a hermetically-sealed box to avoid washing and mixing during the ascent.

177 After recovery, the whole assemblage recovered on each TRAC was directly fixed on board

178 in $10 \%$ formalin in filtered seawater, thus keeping the three-dimensional structure of the faunal

179 community (Zbinden et al., 2003). Later, in the laboratory, samples were transferred to $70 \%$ ethanol.

180 Organisms were sorted under a dissecting microscope and identified to the lowest taxonomic level

181 possible using morphological characters, published species descriptions (Desbruyères et al., 2006)

182 and personal advice on polynoid polychaetes (Daniel Desbruyères, IFREMER, pers.

183 communication). Twenty-four taxa were identified in total (data not shown). Specimens of each taxa

184 were counted and consequently the density of each taxa within TRAC (volume $=1.77 \mathrm{dm}^{3}$ ), was

185 calculated (Table 2). Feeding guilds (bacterivore, detritivore or predator) were assigned based upon

186 known feeding biology from the literature where available and on the model of Bergquist et al.

187 (2007) (Table 2). Only dominant taxa were used for stable isotopes analyses (Table 2).

\subsection{Sample preparation for stable isotope analyses}

Seven invertebrate taxa recovered from TRACs deployed on the alvinellid and the siboglinid

191 habitats were analyzed. Due to the very few colonists on TRACs deployed on bare basalt (Table 2),

192 no stable isotopes analyses (SIA) were carried out on these samples. For large animals such as the

193 polychaete Alvinella pompejana, SIA were conducted on tissues of each specimen separately $(n=5$

194 for each TRAC). We analyzed the body wall removing the digestive tract and the episymbiotic 
195 bacteria that were attached to the dorsal surface. These episymbionts were removed under a

196 dissecting microscope using forceps. For the gastropod Lepetodrilus elevatus, tissues separated from

197 the shell of 20 specimens were pooled to obtain enough material for SIA. Similarly, SIA were

198 conducted on pools of 3 specimens of the polychaetes Lepidonotopodium riftense and

199 Branchinotogluma hessleri, on pools of 2 specimens of the polychaete $B$. sandersi, on pools of 20

200 specimens of Ventiella sulfuris and on pools of 100 specimens of dirivultid copepods with similar 201 morphotypes. Tissues were rinsed with distilled water, oven-dried at $60{ }^{\circ} \mathrm{C}$ for $48 \mathrm{~h}$ and ground to 202 powder with a mortar and pestle. To avoid significant changes in $\delta^{15} \mathrm{~N}$ isotopic composition, no $\mathrm{HCl}$ 203 was used to remove carbonates (Kaehler and Pakhomov, 2001). Preservation in formaldehyde and 204 ethanol can lead to bias in the SIA, as ethanol may increase $\delta^{13} \mathrm{C}$ while formaldehyde may decrease it 205 (Kaehler and Pakhomov, 2001). However, previous SIA performed on the same type of 206 hydrothermal vent metazoans that were fixed in formaldehyde and later transferred to ethanol, 207 consistently showed no significant differences from frozen samples (Bergquist et al., 2007; De

208 Busserolles et al., 2009). Finally, we did not perform any lipid treatment since the C:N ratios of all 209 organisms studied for SIA were between 3 and 4 (Post et al., 2007).

For each species, samples were prepared for analyses in tin combustion capsules $(1 \mathrm{mg} \pm 0.1)$

211 and analyzed using a CHN elemental analyzer (EuroVector, Milan, Italy). The resultant gas was analyzed online in an isotope ratio mass spectrometer (IRMS) (GV IsoPrime, UK) to determine

213 carbon and nitrogen stable isotope ratios. Stable isotopic data are expressed in permil (\%o), and

214 quantify the relative difference between the rare-to-common isotope ratio in a sample and the 215 corresponding conventional standard, defined as Pee Dee Belemnite (PDB) for carbon ratios, and 216 atmospheric $\mathrm{N}_{2}$ for nitrogen ratios, according to the following equation:

$217 \delta(X)=\left[\left(\frac{R_{\text {sample }}}{R_{\text {standard }}}\right)-1\right] * 1000$ 
218 where $X(\%)$ is ${ }^{13} \mathrm{C}$ or ${ }^{15} \mathrm{~N}$ abundance and $R$ is the ${ }^{13} \mathrm{C}:{ }^{12} \mathrm{C}$ or ${ }^{15} \mathrm{~N}:{ }^{14} \mathrm{~N}$ ratios. The internal standards 219 used were USGS $40\left(\delta^{13} \mathrm{C}=-26.8 \% ; \delta^{15} \mathrm{~N}=-4.5 \%\right)$ and USGS $41\left(\delta^{13} \mathrm{C}=37.6 \% ; \delta^{15} \mathrm{~N}=47.6 \%\right.$ ) 220 from the International Atomic Energy Agency. The typical analytical precision was $\pm 0.05 \%$ for 221 carbon and $\pm 0.12 \%$ for nitrogen.

\subsection{Trophic position}

We used the formula proposed by Post (2002) to estimate the trophic position (TP) of the metazoans that colonized TRACs, using the average $\delta^{15} \mathrm{~N}$ ratio of Alvinella pompejana episymbionts and stable isotopic ratios $\left(\delta^{13} \mathrm{C}=-12.4 \% ; \delta^{15} \mathrm{~N}=4.8\right)$ are in the range of stable isotopic ratios of Epsilonproteobacteria from EPR 9 $50 \mathrm{~N}$ (Campbell et al., 2003), viewed as free-living bacteria and primary producers at diffuse-flow hydrothermal vents (Bergquist et al., 2007; Govenar, 2012). We have adjusted the trophic fractionation to $3.3 \%$ in $\delta^{15} \mathrm{~N}$ for microbial diet and $1.4 \%$ in $\delta^{15} \mathrm{~N}$ for invertebrate diets (predators) according to Bergquist et al. (2007):

$$
\mathrm{TP}=\left(\delta^{15} \mathrm{~N}_{\text {organism }}-\delta^{15} \mathrm{~N}_{\text {epibionts }}\right) / 3.3+1 \text { or } \mathrm{TP}=\left(\delta^{15} \mathrm{~N}_{\text {organism }}-\delta^{15} \mathrm{~N}_{\text {epibionts }}\right) / 1.4+1
$$

\subsection{Statistical analyses}

To examine the variation in food sources between taxa recovered from deployments within the alvinellid habitat compared to the taxa recovered from deployments within the siboglinid habitat, 238 we used a Bartlett's test to test differences between variances of $\delta^{13} \mathrm{C}$ values (MINITAB version 15).

239 To determine whether $\delta^{13} \mathrm{C}$ ratios of Alvinella pompejana differ between colonization experiment 240 duration (4d, 13d and 33d) within the alvinellid habitats, a one-way ANOVA was carried out and 241 significant differences were assessed by using a post-hoc Tukey test (MINITAB version 15). 


\section{RESULTS}

\subsection{Temperature and deployment duration}

Mean temperatures that occurred within TRAC deployed on alvinellids for 4 days at the TICA site and for 33 days at the BIO_9 site were in the same range $\left(8.6{ }^{\circ} \mathrm{C} \pm 2.7 ; 6.3{ }^{\circ} \mathrm{C} \pm 1.9\right.$ and $8.7^{\circ} \mathrm{C} \pm 2.4$ respectively; Table 1). During the 13 -day deployment on alvinellids at the TICA site, both temperature probes exhibited a steep and severe temperature increase, far beyond the maximum temperature of $20^{\circ} \mathrm{C}$ initially chosen for our deployment (Fig.3c). Temperature rose over $150{ }^{\circ} \mathrm{C}$ and was probably much higher, but precise measurement of maximum temperature was not obtained because it exceeded the accuracy limit of the probes (Fig.3c). A small sulfide spire, about $10 \mathrm{~cm}$ high, grew within the TRAC during the 13-day deployment interval. The tip of the probes was very close to the growing spire, and was probably bathed by high temperature fluid expelled from the spire. Temperature was highly variable and changed within minutes in this alvinellid habitat (Fig.3c). Within the siboglinid habitat, the same temporal trend was observed, but the amplitude of variation was reduced (Fig.3b). Mean temperatures that occurred within TRACs deployed for 4 days and 29 days at the TICA site among siboglinid habitat were in the same range $\left(\sim 5^{\circ} \mathrm{C}\right)$, but less than those mean temperatures recorded during deployment within alvinellid habitats for the same duration (Table 1). However, as was the case in the 13-day deployment among alvinellid habitat (though less extreme), high temperatures in TRAC deployed within the siboglinid habitat were also recorded (up to $\sim 29^{\circ} \mathrm{C}$ ) giving a mean temperature of $10.5^{\circ} \mathrm{C} \pm 4.9$ (Fig.3b; Table 1). By way of a control, TRACs deployed on bare basalt had more or less stable temperature throughout the different deployment duration (4 days, 13 days and 29 days), with a mean temperature $\sim 2{ }^{\circ} \mathrm{C}$ similar to ambient deep-sea temperature (Fig.3a; Table 1).

\subsection{Stable isotopes values of carbon and nitrogen in alvinellid habitat}


In the alvinellid habitat (Fig. 4a), the amphipod Ventiella sulfuris and the gastropod

268 Lepetodrilus elevatus yielded lighter $\delta^{13} \mathrm{C}(-13.3 /-13.1 \%$ and $-13.2 \%$ respectively) while the heavier

$269 \delta \delta^{13} \mathrm{C}$ was recorded for the polychaete Alvinella pompejana $(-10.6 \% \pm \pm 0.9 \%)$ and dirivultid copepods

270 (-10.6\%o), after 4 days of deployment. Both latter taxa exhibited the same range of $\delta^{15} \mathrm{~N}$ isotopic

271 ratios $(6.5 \%)$ and became more $\delta^{13} \mathrm{C}$ depleted after 13 days $\left(-11.9 \%_{0} \pm 0.3 \%\right.$; $-12.3 \%$ respectively)

272 compared to the 4-day deployment (Fig. 4a). Dirivultid copepods were absent from TRAC deployed 273 on alvinellid habitat in Bio_9 (Table 2). Significant differences in $\delta^{13} \mathrm{C}$ of $A$. pompejana were tested 274 between colonization experiment duration $(4 \mathrm{~d}, 13 \mathrm{~d}$ and $33 \mathrm{~d})\left(F_{(1,2)}=7.47 ; p<0.01\right)$. A post-hoc

275 Tukey test showed that $\delta^{13} \mathrm{C}$ values of $A$. pompejana recovered from the 4-day deployment are 276 different from those of the 13-day deployment $(p<0.05)$ (Fig.4a).

One of the possible primary producers, the episymbionts of $A$. pompejana displayed the 278 lighter $\delta^{15} \mathrm{~N}$ values (4.8-5.1\%) and were more $\delta{ }^{13} \mathrm{C}$ depleted (-12.1 to $-12.5 \%$ ) than to their host 279 (data seen previously) (Fig. 4a). Thus after 4 days of deployment, trophic fractionation ( $\Delta$ hereafter) 280 between $A$. pompejana and its episymbionts, was $2.2 \%$ for $\delta^{13} \mathrm{C}$ and $1.5 \%$ for $\delta^{15} \mathrm{~N}$ while $\Delta$ of $\delta^{13} \mathrm{C}$ 281 were $0.3 \%$ and $0.8 \%$ and $\Delta$ of $\delta^{15} \mathrm{~N}$ were $1.4 \%$ and $1.8 \%$ after 13 - and 33-day deployments 282 respectively (Fig.4a).

\subsection{Stable isotopes values of carbon and nitrogen in siboglinid habitat}

A temporal variability in stable isotopic composition of target invertebrates was observed in the Tevnia jerichonana habitat during the course of the experiment (Fig. 4b). The gastropod Lepetodrilus elevatus yielded lighter $\delta^{13} \mathrm{C}$ values after 13 days (-14.2\%) and 29 days (-14.5\%o) of 
292 12.3\%o respectively). The polynoid Lepidonotopodium riftense was highly $\delta^{13} \mathrm{C}$ depleted compared 293 to the rest of the taxa in the three temporal colonization experiments and also displayed a very wide 294 range of $\delta^{15} \mathrm{~N}$ values (from 6.7 to 10.8\%o) (Fig. 4b). Dirivultid copepods collected after 4 days of 295 deployment (Fig. 4b) had the lighter value of $\delta^{15} \mathrm{~N}(4.1 \%$ ) among the metazoans and prokaryotes 296 analyzed in this study.

\subsection{Spatial variability of stable isotope ratios} habitat were significantly more homogeneous (-13.3 to $-10.1 \%$ ) than those recovered in the Tevnia jerichonana habitat (-15.6 to $-10.5 \%$; Bartlett's test $F=0.37 ; p<0.05)$. Both dirivultid copepods and the limpet Lepetodrilus elevatus were more $\delta^{13} \mathrm{C}$ depleted in the siboglinid habitat than in the alvinellid habitat (Fig. 4a, b). Stable isotope values of the amphipod Ventiella sulfuris were very similar $\left(\delta^{13} \mathrm{C}:-13.1\right.$ to $-13.7 \%$; $\delta^{15} \mathrm{~N}: 8.3$ to $8.6 \%$ ) in specimens collected in the six TRACs deployed in the two different habitats (alvinellid and siboglinid habitats) over time and also in the different sites (Fig. 4a, b).

\subsection{Food web structures}

Three main trophic positions (TP) emerged from the Table 3 giving potentially four trophic levels including primary producer, the episymbionts (attached bacteria of Alvinella pompejana) as

311 the first trophic level (TP ranging 1). The first group of primary consumers (TP ranging between $312 \sim 1$ and $\sim 2$ ) including A. pompejana and dirivultid copepods was seen as bacterivores. A second 313 group of primary consumers (TP ranging between $\sim 2$ and $\sim 3$ ) including Ventiella sulfuris and the 314 limpet Lepetodrilus elevatus was seen as detritivores. A third group involving the secondary consumers (TP ranging above 3), was seen to comprise of predators including the three polynoid polychaetes. The two scale worms Branchinotogluma sandersi and Lepidonotopodium riftense may 
317 switch their diet and become detritivores (Table 3). Within the alvinellid habitat, no changes of

318 feeding guilds occurred during the course of the experiments between the 4-day, 13-day (TICA site)

319 and also the 33-day experiments (Bio_9 site). However, within the siboglinid habitat, two species

320 switched their feeding strategy in both directions from detritivore to predator from the 4-day to the

321 29-day experiments. The trophic position of dirivultid copepods had a value lower than the trophic

322 baseline in the 4-day experiments. For the seven invertebrate taxa encountered in any TRACs or

323 habitats, general mean stable isotope ratios of $\delta^{13} \mathrm{C}$ and $\delta^{15} \mathrm{~N}$ with respective standard deviation are

324 reported in Table 4. Standard deviations in $\delta^{13} \mathrm{C}$ of B. sandersi, L. riftense, B. hessleri, V. sulfuris and

325 A. pompejana were less than 1.0 (between 0.3 and 0.9 ) compared to those in $\delta^{13} \mathrm{C}$ of L. elevatus and

326 the dirivultid copepods that are higher than 1.0. $(\mathrm{SD}=1.4)$.

\section{DISCUSSION}

Our colonization experiments were conducted at $9^{\circ} 50^{`} \mathrm{~N}$ at the East Pacific Rise on vigorous vents right after a volcanic eruption, when the fauna was still in the early stages of colonization as evidenced by the presence of the siboglinid Tevnia jerichonana. This sessile chemosynthetic species is generally one of the first to colonize new diffuse-flow vents, and is usually replaced at a later successional stage by the siboglinid Riftia pachyptila (Shank et al., 1998; Govenar, 2010).

334 Hydrothermal vents at EPR 950’ $\mathrm{N}$ in November/December 2006 appeared to be at a similar 335 successional stage to the one described by Shank et al. (1998), 10 months after the 1991 eruption at 336 this site (Bennet et al., 2011).

\subsection{Variation of the food sources and links to temperature}

The Bartlett test of homoscedasticity revealed significantly larger variance in the carbon

340 stable isotope ratios of taxa collected within TRACs deployed in Tevnia jerichonana habitat (Fig.4b) 341 than those deployed in Alvinella pompejana habitat (Fig.4a). This might indicate a greater diversity 
342 of food sources with different isotopic ratios in the former habitat. At hydrothermal vents,

343 chemosynthetic primary producers are diverse both phylogenetically and metabolically (Sievert and

344 Vetriani, 2012) but little is known on the relative contribution of these groups to the diets of primary

345 consumers (Govenar, 2012). Though somewhat dependent on the colonization deployment duration

346 (4d, 13d and 29/33d), generally average temperature was highest within TRACs deployed on the

347 alvinellid habitat when compared to the siboglinid habitat (Table 1). A number of factors may co-

348 vary with temperature at hydrothermal vents including hydrogen sulfide and pH (Le Bris et al., 2006;

349 Gollner et al., 2010). For example, within T. jerichonana habitat at the TICA site, Nees et al. (2009)

350 formerly recorded for the same range of temperatures $\left(2-30^{\circ} \mathrm{C}\right)$ as those recorded for the 2-week

351 colonization experiments in siboglinid habitat (Table 1), some sulfide $\left(\mathrm{S}_{\text {free }}\right)$ concentrations up to 549

$352 \mu \mathrm{m}$ and comparatively low concentrations of $\mathrm{O}_{2}($ mean $=27.0 \mu \mathrm{M})$. Several sulfur-oxidizing

353 chemoautotrophic bacteria (Epsilonproteobacteria, Aquifales and Gammaproteobacteria) may be

354 present, but as temperatures (and certainly sulfide and oxygen concentrations) were different

355 between TRACs deployed in alvinellid and sibloglinid habitats, it is likely that any variation in the

356 distribution of chemoautotrophic organisms is dependent upon bacteria-specific temperature regimes

357 (Sievert and Vetriani, 2012). The spatial heterogeneity in stable isotopic ratios within TRACs may

358 be due to these in situ populations of free-living microorganisms with heterogeneous carbon isotopic

359 compositions that are microhabitat dependent (Van Dover and Fry, 1994). For example, the $\delta^{13} \mathrm{C}$

360 values of bacterivorous dirivultid copepods recovered from TRACs deployed in the siboglinid

361 habitat were lighter than those recovered from TRACs deployed in the alvinellid habitat. First of all,

362 this could reveal that the bacteria that contribute most to the diet of specimens collected within

363 TRACs in sibloginid habitat after 4 days and 13 days of deployments differ from those that

364 contribute most to the diet of specimens collected within TRACs in alvinellid habitat after 4 days

365 and 13 days of deployments. Alternatively stable isotope values of bacteria in these two particular

366 habitats, which are only separated by 4 meters, may differ due to variability in the chemical 
microenvironment even if the diversity and consumption ratios of different bacteria available for the

368 consumers is the same. This fact was observed by De Busserolles et al. (2009) in the Tour Eiffel

369 edifice at Mid-Atlantic ridge. Finally, there may be a notable contribution to the specimens' diet

370 from Particulate Organic Matter (POM) within the siboglinid habitat, resulting in much depleted

$371 \delta^{13} \mathrm{C}$ values in tissues of consumers collected in this habitat, when compared to those deployed in the

372 alvinellid habitat (shift to the left in Fig.4b). Episymbiotic and free chemolithoautotrophic bacteria

373 may be the main food sources in the alvinellid habitat resulting in heavier carbon stable isotopes

374 ratios in this study. Epsilonproteobacteria are known to be the dominant free chemolithoautotrophic

375 bacteria on vent edifices at the $9^{\circ}$ N EPR (Sievert et al., 2009; Sievert and Vetriani, 2012) and use the

376 reverse tricarboxylic acid (rTCA) cycle as a carbon fixation pathway (Campbell et al., 2006),

377 resulting in heavier $\delta^{13} \mathrm{C}$ values between -12 and $-8 \%$. This scenario is in line with the work of

378 Limén et al. (2007) who demonstrated that the further away from the flow the organisms were

379 sampled, the greater the role of POM in their diet, resulting in depleted $\delta^{13} \mathrm{C}$ values compared to

380 organisms located closed to the fluid emission. As the metazoans' diet was dominated by microbes,

381 their $\delta^{13} \mathrm{C}$ values were heavier.

\subsection{Variation of the diet of the primary consumers}

\subsubsection{Bacterivores}

Within a one-month window and at a distance of only 4 meters from a given sulfide edifice, stable isotope values for a given taxa displayed mostly visually (Fig.4 a, b) or/and significantly variability within the colonization experiments. The variability of both $\delta^{13} \mathrm{C}$ and $\delta^{15} \mathrm{~N}$ reported in different studies are listed in Table 4. In our experiments, we highlighted the temporal variability (within 13 days to one month) of stable isotope ratios for two bacterivorous taxa, Alvinella pompejana and dirivultid copepods. After the 2-week at the TICA site and the 1-month at the Bio_9 
experiments, reflecting an alteration in carbon sources during the course of both colonization experiments (Fig. 4a). In these two TRACs (13d and 33d), a micro-environment may have established. According to Taylor et al. (1999) and Alain et al. (2004), the succession of different populations of microbes ultimately formed visible mats covering TRACs deployed at EPR within which Epsilonproteobacteria were identified as being the first pioneer and dominant microbes among other phylotypes. Visible mats were observed during the recovery of the TRACs, both on alvinellid habitats (highly covered) and on sibloglinid habitats (sparsely covered) (Table 1).

Epsilonproteobacteria are also the dominant phylotype known to form a dense epibiosis layer on the dorsal surface of A. pompejana (Le Bris and Gaill, 2010). These bacteria primarily use the rTCA cycle as a carbon fixation pathway and at $9^{\circ} 50 \mathrm{~N} E P R, \delta^{13} \mathrm{C}$ and $\delta^{15} \mathrm{~N}$ values are between $12 \%$ and $-8 \%$ and 0 to $4 \%$ respectively (Campbell et al., 2003). A shift in the diet of the bacterivorous $A$. pompejana and dirivultid copepods from the 4-day experiment to the 13- and 33day experiments, could represent a change in the bacterial community within TRACs compared to natural habitat. This suggests a fast tissue turnover rate in these two taxa. These two bacterivores also share almost identical $\delta^{13} \mathrm{C}$ and $\delta^{15} \mathrm{~N}$ values, indicating that they may share the same trophic niche and may be in competition for the same food resource (chemoautotrophic bacteria). This would provide an explanation for the decrease in density of copepods in the 2-week colonization experiment and their disappearance after 1-month within alvinellid habitat (Table 2). Within our study, we can exclude the possibility that $A$. pompejana may feed on dirivultid copepods, such as is seen with paralvinellids Paralvinella sulfincola and $P$. palmiformis scavenging on the dirivultid copepod Stygiopontius quadrispinosus in Northeast Pacific (Limén et al., 2008), based both upon stable nitrogen and carbon isotopic values. In the siboglinid habitat, stable nitrogen and carbon isotopic values of dirivultid copepods recovered after 4 days and 13 days within colonization experiments, were very different, especially for the $\delta^{15} \mathrm{~N}$ (Fig.4b). In table 3, the trophic position was lower than the trophic baseline for the dirivultid copepods sampled within the 4-day colonization 
417 experiments, reflecting the diet that they consumed in their natural habitat. The change in $\delta^{15} \mathrm{~N}$ after

41813 days of deployment may highlight a change in feeding strategy of these dirivultid copepods.

\subsubsection{Detritivores}

Other marine invertebrates such as the amphipod Ventiella sulfuris and the gastropod

Lepetodrilus elevatus may also feed on free-living micro-organisms. Lepetodrilus sp. are generally

considered as bacterivores (Tables 2,4 ) but are also thought to employ suspension and/or deposit

feeding with epibiotic bacteria (Gammaproteobacteria) on its gills being an alternative nutritional resource (Goffredi et al., 2004; Levesque et al., 2006; Bates, 2007). In our experiments $\delta^{13} \mathrm{C}$ values of these two bacterivorous species were lighter when compared to $\delta^{13} \mathrm{C}$ values of the two other bacterivorous species, Alvinella pompejana and dirivultid copepods, and were subsequently largely $\delta^{13} \mathrm{C}$ depleted in comparison to Epsilonproteobacteria at EPR $9^{\circ} 50^{`} \mathrm{~N}$ (Campbell et al., 2003). Therefore the chemoautotrophic bacteria cannot be the only carbon source for the gastropod or the amphipod, as in this case, enrichment in $\delta^{13} \mathrm{C}$ would be expected (trophic shift to the right in Figs. on another type of food that is less rich in $\delta^{13} \mathrm{C}$ such as POM, which is a mixture of bacteria and decomposed organic matter. Limén et al. (2007), using a two-source mixing model (Phillips and Gregg, 2003), demonstrated that POM and chemoautotrophic bacteria accounted for $40 \%$ and $60 \%$ respectively of the diet of the limpet L. fucensis, collected in an intermediate zone of a vent sulfide

436 edifice located on Juan de Fuca Ridge. At this lower flow regime, $\delta^{13} \mathrm{C}$ values of POM ranged from 43718.3 to $-19.3 \%$ and $\delta^{15} \mathrm{~N}$ from 4.6 to $7.4 \%$ (Limén et al., 2007). A third food source, 438 Gammaproteobacteria, was observed in L. fucensis within the lamellae of its gills (Bates, 2007) 439 leading to different carbon and nitrogen isotopic ratios. Regarding the amphipod, Corbari et al. 440 (2012) found cuticles and setae of A. pompejana and Epsilonproteobacteria within the digestive tract 441 of $V$. sulfuris sampled during similar periods and sites to those in our study. These last authors 
suggested that the amphipod may actually feed on the episymbionts of the alvinellid worm. However our stable isotopic data do not sustain this hypothesis as $\delta^{13} \mathrm{C}$ of $V$. sulfuris would have been more enriched and a characteristic shift to the right would have been observed compared to the episymbionts of A. pompejana (Fig.4a). Both the limpet and the amphipod may have a mixed diet (Figs. 4a, b) and can be regarded both as bacterivores and/or detritivores (Tables 2, 3).

\subsection{Variation in the diet of secondary consumers}

Despite the fact that we cannot completely rule out the influence of extraneous sources of food upon the organisms we studied within TRACs, as the mobile species such as the errant polynoid polychaetes can prey on items outside the TRACs, we can provide a glance into possible predatorprey relationships based on the calculation of the shifts of $1 \%$ in $\delta^{13} \mathrm{C}$ and of $3-4 \%$ in $\delta^{15} \mathrm{~N}$ (De Niro and Epstein, 1978, 1981; Minagawa and Wada, 1984) or 1.4\% for $\delta^{15} \mathrm{~N}$ (Bergquist et al., 2007; De

\section{Busserolles et al., 2009). For instance, the carnivorous polynoid polychaete Branchinotogluma} hessleri recovered after 1 month within the alvinellid habitat (Table 1) may have fed on both Ventiella sulfuris and Lepetodrilus elevatus. In TRACs deployed in the siboglinid habitat, we were able to identify three potential predators (Table 3): the three polynoid polychaetes $B$. hessleri, $B$. sandersi and Lepidonotopodium riftense. These three species did not have the same $\delta^{13} \mathrm{C}$ isotopic values and therefore may either hunt on different types of prey or share the same range of prey but with differing magnitudes of reliance on each prey species. In the one-month experiment deployed in the siboglinid habitat (Table 1), $\delta^{15} \mathrm{~N}$ values of the polynoid $B$. sandersi were heavier than those recorded in the 4-day experiment (Fig.4b), possibly due to the increase in the number of species within the TRAC, which increased the complexity of the food web and the number of trophic positions in a classical pyramidal food web. In this short-term deployment, $\delta^{15} \mathrm{~N}$ values of $B$. sandersi reflect the nutritional resources on which the worms depend in their natural habitat 
467 (Table 3). However, the $\delta^{13} \mathrm{C}$ of $B$. sandersi is quite enriched compared to detritical organic matter 468 (POM) and this could indicate that this polychaete worm was preying or scavenging on dead or alive 469 Tevnia jerichonana branchial plume tissue, which would explain the empty tubes of this siboglinid 470 tubeworm found in this TRAC (data not shown). Unfortunately, we do not have any isotopic ratios $471\left(\delta^{13} \mathrm{C}\right.$ and $\left.\delta^{15} \mathrm{~N}\right)$ of this siboglinid tubeworm from the literature to compare to our data. Bergquist et 472 al. (2007) observed some scale worms such as L. piscesae feeding on the siboglinid Ridgeia piscesae $473\left(\delta^{13} \mathrm{C}=-12.5\right.$ to $-11.0 \%$ and $\delta^{15} \mathrm{~N}=-1.7$ to $2.5 \%$; Levesque et al., 2006). In this study, B. sandersi 474 became the top predator after one month (Table 3) and thus may have consumed a mixed diet of 475 different species possibly including amphipods (Fig.4b). The other top predator in the 2-week 476 experiment in the siboglinid habitat (Table 1) was B. hessleri, which may prey on $V$. sulfuris $\left(\Delta \delta^{13} \mathrm{C}\right.$ $477=0.3 \%$ and $\Delta \delta^{15} \mathrm{~N}=3.8 \%$ ) (Fig.4b). The third polynoid L. riftense was much depleted in $\delta^{13} \mathrm{C}(-$ 478 15.5\%o) could possibly be due to the POM contribution to its diet, not dissimilar to the polynoid 479 Lepidonotopodium sp. sampled by Limén et al. (2007) (Fig.4b). Levesque et al. (2006) observed this 480 latter species feeding directly on POM. It is possible that in our study in the long-term experiments 481 in the siboglinid habitat (Table 3), the polychaete L. riftense may have fed directly on POM (Fig.4b).

482 Indeed, the $\delta^{15} \mathrm{~N}$ was very light for this polychaete species, which is assumed to be a predator, and $483 \delta^{13} \mathrm{C}$ was depleted compared to those of the other taxa (Fig.4a, b). Initially in Table 2, this polychaete 484 was seen as a predator only, but in our study after one month this worm switches its diet to 485 detritivore (Table 3).

\subsection{Some insight on Alvinella Pompejana's diet}

According to the literature (references herein), the trophic fractionation $(\Delta)$ of both $\delta^{13} \mathrm{C}$ and $489 \delta^{15} \mathrm{~N}$ between prey and predator is usually $0-1 \%$ and 3-4\%o respectively. Mc Cutchan et al. (2003) 490 demonstrated that $\Delta$ of $\delta^{15} \mathrm{~N}$ can be around $2 \%$ between primary consumer and primary producer, 491 which is closer to our calculations for the 2-week and 1-month experiments between the alvinellid 
492

493

494

495

polychaete and its episymbionts. This indicates that episymbiotic communities could have been used as a food source by Alvinella pompejana during the 2-week and the one-month experiments. Pioneer authors (Desbruyères et al., 1983; Gaill et al., 1987; Desbruyères et al., 1998) working on epibiosis of A. pompejana suggested that these bacteria could be used as a food source by the alvinellid polychaetes. Analyses of lipid biomarkers were undertaken on both A. pompejana and its episymbionts (Phleger et al., 2005), but authors were unable to confirm the hypothesis that the worm was actually feeding on its episymbionts. The only conclusion of their analyses was that, thanks to the lipids, fatty acid and sterol profiles, there was strong evidence for bacterial dietary input for $A$. pompejana suggesting that they were bacterivores, which we also infer in this paper from the TP calculation (Table 3). In a recent paper (Grzymski et al., 2008), a specimen of A. pompejana was shown grazing on the back of another conspecific. Likewise, Shinkaia crosnieri, a vent galatheid crab, was observed grazing on its epibiotic bacteria in an aquarium (Miyake et al., 2007). It was hypothesized that this vent crustacean may harvest its episymbionts to feed, but that the crab also feeds on free living bacteria (Goffredi et al., 2008). Again, the limpet Lepetodrilus fucensis hosts filamentous episymbionts on its gill lamellae that may be ingested directly by the gill epithelium (Bates, 2007). Based on the stable isotopic values in the 2-week and 1-month experiments in our study, A. pompejana may have used its episymbionts or those from a conspecific as a food source during the TRAC experiments.

\subsection{Consequences on the food web structure at a vent}

Overall, food web structures (Fig.5) established within TRACs deployed both in the alvinellid and the siboglinid habitats appear to be similar to models described previously by

Bergquist et al. (2007) from vent community issued from Juan de Fuca ridge and recently reviewed by Govenar (2012) from vent communities issued from both Juan de Fuca Ridge and East Pacific Rise. In general we have 3 to 4 trophic levels with multiple food sources for each consumer as seen 
517 in Bergquist et al. (2007) and Govenar (2012) (Fig.5). Primary producers may be divided into three 518 groups, (1) free-living bacteria colonizing TRAC, mostly Epsilonproteobacteria, (2) episymbiotic 519 bacteria attached to invertebrates, (3) Particulate Organic Matter resulting from a mixture of detritus 520 from decaying bodies, mucus, microbial cells and photosynthetically-derived surface material and associated bacteria. Primary consumers may be divided into two groups, (1) bacterivores feeding on

522 free-living bacteria within TRACs or on episymbiotic bacteria, (2) detritivores or scavengers feeding on detritus issued from decomposition of free-living bacteria, episymbionts and invertebrates and photosynthetically-derived surface material and associated bacteria. Secondary consumers are predators feeding on primary consumers either bacterivores or detritivores. Spatial differences may be observed in food web structures within TRACs deployed in alvinellids habitat dominated by

527 primary consumers (bacterivores and detritivores) compared to those deployed in siboglinid habitats, 528 where a higher number of predators (secondary consumers) seems to occur (Fig.4a, b; Table 3). 529 Temporal differences in food web structures within TRACs may be more highlighted in our study 530 both in the alvinellid and siboglinid habitats with an increase of detritivores compared to 531 bacterivores over time (Fig.4a, b; Table 3). Within our study, trophic specialists (most of the species) that have narrow $\delta^{13} \mathrm{C}$ values seems 533 to coexist with trophic generalists (dirivultid copepods and limpet) that have larger $\delta^{13} \mathrm{C}$ values 534 (Table 4) confirming the hypothesis of resource partitioning at vent habitat (Bergquist et al., 2007). 535 However, De Busserolles et al. (2009) argued this hypothesis, indicating that the variance of $\delta^{13} \mathrm{C}$ 536 was more linked to the variations of environmental conditions and the breadth of the trophic niche, 537 concluding it was not the best tool to assess feeding strategies at vent. Using our data, we can agree 538 with these last authors as the two polynoids Lepidonotopodium riftense and Branchinotogluma 539 sandersi considered to be predators (secondary consumers) seen in Bergquist et al. 2007 (Table 2) 540 were seen as detritivores/scavengers (primary consumers) in this study for some of the colonization 541 experiments (Table 3). These two species have switched their diet evidence from a decrease or an 
542 increase in the $\delta^{15} \mathrm{~N}$ values (and trophic levels) however the $\delta^{13} \mathrm{C}$ ratios are narrow and not variable

543 leading to specialist feeding strategies in theory, but in fact are more related to generalist strategies.

$544 \quad$ Plasticity in trophic relationships at vents seems to be common in secondary consumers; it

545 does not only occur in Annelid polychaetes like this study, but was seen in Mollusk gastropods and

546 in Arthropods crustacean in other studies at vents (Govenar, 2012). This switch in diet occurred also

547 within our study in the primary consumer such as Alvinella pompejana, the gastropod Lepetodrilus

548 elevatus and the dirivultid copepods. Paralvinellid polychaetes were seen at the Juan de Fuca Ridge

549 to switch its bacterial diet to detritical diet while the fluid flux was diminishing (Levesque et al.,

$5502003 ; 2005)$. This strategy to switch its diet may be an adaptation for taxa living at hydrothermal

551 vents where hydrothermal fluids are unstable (Luther et al., 2001; Le Bris et al., 2006; this study),

552 altering the availability of resources for chemosynthetic primary producers. This study may help to

553 increase the knowledge of the complexity of the food web at hydrothermal vents and better

554 understanding communities' resilience following environmental changes.

\section{CONCLUSION}

To conclude we demonstrated by using colonization experiments that some spatial

558 heterogeneity in the $\delta^{13} \mathrm{C}$ of consumers may be observed on a vent edifice at the meter scale, arising

559 from the partitioning of food resources. Our study suggested that within a short period (one month),

560 both $\delta^{13} \mathrm{C}$ and $\delta^{15} \mathrm{~N}$ values of some primary and secondary consumers such as Lepidonotopodium

561 riftense, Branchinotogluma sandersi, Alvinella pompejana, Lepetodrilus elevatus and dirivultid

562 copepods varied greatly indicating first of all, a fast tissue turnover and secondly, a switch in feeding

563 strategy or food sources consumption for some invertebrates taxa at this hydrothermal vent. Finally,

564 through the analysis of stable isotopes ratios of alvinellid polychaetes and their episymbionts that we

565 recovered in TRACs, we provided evidence that these attached bacteria may have formed part of the

566 diet of these worms during these in situ experiments. 


\section{ACKNOWLEDGEMENTS}

We are grateful to the PIs and chief scientists of the LADDER cruises, Lauren Mullineaux,

Andreas Thurnherr, Jim Ledwell for allowing us to deploy our TRACs. We also thank the captain and crews of the R/V Atlantis and the submersible Alvin (WHOI, USA). We are grateful to Laure Corbari and Nadine Le Bris who helped deploying and recovering TRACs during the cruises. We are indebted to Marie-Paul Bataillé for her technical support in IRMS. We acknowledge financial support from UPMC (France), CNRS (France) and US National Science Foundation (OCE0424953). We would like to thank the three anonymous reviewers for the improvement of this paper. This manuscript has been partially professionally edited by Daphné Goodfellow and we thank her. Finally, we acknowledge Sven Laming for editing this manuscript.

\section{REFERENCES}

Alain, K., Zbinden, M., Le Bris, N., Lesongeur, F., Quérellou, J., Gaill, F., Cambon-Bonavita, M.A., 2004. Early steps in microbial colonization processes at deep-sea hydrothermal vents. Environmental Microbiology 6 (3), 227-241.

Bates, A.E., 2007. Persistence, morphology, and nutritional state of a gastropod hosted bacterial symbiosis in different levels of hydrothermal vent flux. Marine Biology 152, 557-568.

Bennett, S.A., Statham, P.J., Green, D.R.H., Le Bris, N., McDermott, J.M., Prado, F., Rouxel, O.J., German, C.R., 2011. Dissolved and particulate organic carbon in hydrothermal plumes from the East Pacific Rise, 950'N. Deep-Sea Research I 58, 922-931. 
591 Bergquist, D.C., Eckner, J.T., Urcuyo, I.A., Cordes, E.E., Hourdez, S., Macko, S.A., Fisher, C.R., 592 2007. Using stable isotopes and quantitative community characteristics to determine a local 593 hydrothermal vent food web. Marine Ecology Progress Series 330, 49-65.

594

595 Campbell, B.J., Engel, A.S., Porter, M.L., Takai, K., 2006. The versatile epsilonproteobacteria: key 596 players in sulphidic habitats. Nature Reviews Microbiology 4, 458-468.

597

598 Campbell, B.J., Stein, J.L., Cary, S.C., 2003. Evidence of Chemolithoautotrophy in the Bacterial 599 Community Associated with Alvinella pompejana, a Hydrothermal Vent Polychaete. Applied and 600 Environmental Microbiology 69 (9), 5070-5078.

601

602 Childress, J.J., Fisher, C.R., 1992. The biology of hydrothermal vent animals: physiology, 603 biochemistry and autotrophic symbioses. Oceanography and Marine Biology Annual Review 30, $604 \quad 337-441$.

605

606 Colaço, A., Dehairs, F., Desbruyères, D., 2002. Nutritional relations of deep-sea hydrothermal fields 607 at the Mid-Atlantic Ridge: a stable isotope approach. Deep-Sea Research I 49, 395-412.

608

609 Corbari, L., Durand, L., Cambon-Bonavita, M.-A., Gaill, F., Compère, P., 2012. New digestive 610 symbiosis in the hydrothermal vent amphipoda Ventiella sulfuris. Comptes Rendus Biologies 335, $611 \quad 142-154$.

612

613 Cuvelier, D., Sarrazin, J., Colaço, A., Copley, J., Desbruyères, D., Glover, A.G., Tyler, P., Santos, 614 R.S., 2009. Distribution and spatial variation of hydrothermal faunal assemblages at Lucky Strike 
615 (Mid-Atlantic Ridge) revealed by high-resolution video images analysis. Deep-Sea Research I 56, $616 \quad 2026-2040$.

617

618 De Busserolles, F., Sarrazin, J., Gauthier, O., Gélinas, Y., Fabri, M.C., Sarradin, P.M., Desbruyères, 619 D., 2009. Are spatial variations in the diets of hydrothermal fauna linked to local environmental 620 conditions? Deep-Sea Research II 56, 1649-1664.

621

DeNiro, M.J., Epstein, S., 1978. Influence of diet on the distribution of carbon isotopes in animals.

Geochimica et Cosmochimica Acta 42, 495-506.

624

DeNiro, M.J., Epstein, S., 1981. Influence of diet on the distribution of nitrogen isotopes in animals.

Geochimica et Cosmochimica Acta 45, 341-351.

627

Desbruyères, D., Segonzac, M., Bright, M., 2006. Handbook of Deep Sea Hydrothermal Vents. Second completely revised edition. Denisia 18: 544pp.

630

Desbruyères, D., Chevaldonné, P., Alayse-Danet, A.M., Caprais, J.C., Cosson, R., Gaill, F.,

Guezennec, J., Hourdez, S., Jollivet, D., Jouin-Toulmond, C., Lallier, F.H., Laubier, L., Riso, R.,

Sarradin, P.M., Toulmond, A., Zal, F., 1998. Biology and ecology of the "Pompeï worm" (Alvinella pompejana Desbruyères and Laubier), a normal dweller of an extreme deep-sea environment. DeepSea Research II 45, 383-422.

636

Desbruyères, D., Gaill, F., Laubier, L., Prieur, D., Rau, G.H., 1983. Unusual nutrition of the pompeii worm Alvinella pompejana (polychaetous annelid) from a hydrothermal vent environment SEM, 
641 Dubois, S., Orvain, F., Marin-Léal, J.C., Ropert, M., Lefebvre, S., 2007. Small-scale spatial

642 variability of food partitioning between cultivated oysters and associated suspension-feeding species,

643 as revealed by stable isotopes. Marine Ecology Progress Series 336, 151-160.

644

645 Fisher, C.R., Childress, J.J., Macko, S.A., Brooks, J.M., 1994. Nutritional interactions in Galapagos

646 Rift hydrothermal vent communities: inferences from stable isotope analyses. Marine Ecology

647 Progress Series 103, 45-55.

648

649 Gaill, F., Desbruyères, D., Prieur, D., 1987. Bacterial communities associated with "Pompei worms"

650 from the East Pacific Rise Hydrothermal Vents: SEM, TEM Observations. Microbial Ecology 13, $651 \quad 129-139$.

652

653 Goffredi, S.K., Jones, W.J., Erhlich, H., Springer, A., Vrijenhoek, R.C., 2008. Epibiotic bacteria 654 associated with the recently discovered Yeti crab, Kiwa hirsuta. Environmental Microbiology 10 655 (10), 2623-2634.

656

657 Goffredi, S.K., Waren, A., Orphan, V.J., Van Dover, C.L., Vrijenhoek, R.C., 2004. Novel forms of 658 structural integration between microbes and a hydrothermal vent gastropod from the Indian Ocean. 659 Applied and Environmental Microbiology 70 (5), 3082-3090.

660

661 Gollner, S., Riemer, B., Arbizu, P., Le Bris, N., Bright, M., 2010. Diversity of meiofauna from the $6629^{\circ} 50$ 'N East Pacific Rise across a gradient of hydrothermal fluid emissions. PLoS ONE 5 (8), 1-14. 663

664 Govenar, B., 2012. Energy transfer through food webs at hydrothermal vents. Oceanography 25(1), $665 \quad 246-255$. 
667 Govenar, B., 2010. Shaping vent and seep communities: habitat provision and modification by 668 foundation species. In: Kiel, S. (Ed.), The Vent and Seep Biota, pp. 403-432.

669

670 Grzymski, J.J., Murray, A.E., Campbell, B.J., Kaplarevic, M., Gao, G.R., Lee, C., Daniel, R., 671 Ghadiri, A., Feldman, R.A., Cary, S.C., 2008. Metagenome analysis of an extreme microbial 672 symbiosis reveals eurythermal adaptation and metabolic flexibility. Proceedings of the National 673 Academy of Sciences of the United States of America 105 (45), 17516-17521.

674

675 Jannasch, H.W., 1985. The chemosynthetic support of life and the microbial diversity at deep-sea 676 hydrothermal vents. Proceedings of the Royal Society of London Series B-Biological Sciences 225 677 (1240), 277-297.

678

679 Juniper, S.K., Jonasson, I.R., Tunnicliffe, V., Southward, A.J., 1992. Influence of a tube-building 680 polychaete on hydrothermal sulphide edifice mineralisation. Geology 20, 895-898.

681

682 Juniper, S.K., Martineu, P., 1995. Alvinellids and sulfides at hydrothermal vents of the eastern 683 Pacific: a review. American Zoology 35, 174-185.

684

685 Kaehler, S., Pakhomov, E.A., 2001. Effects of storage and preservation on the $\delta^{13} \mathrm{C}$ and $\delta^{15} \mathrm{~N}$ 686 signatures of selected marine organisms. Marine Ecology Progress Series 219, 299-304. 687

688 Karl, D.M., 1995. Ecology of free-living hydrothermal vent microbiology communities. In: Karl, 689 D.M. (Ed.), the microbiology of deep-sea hydrothermal vents. CRC Press Inc., Boca Raton, FL, pp. $690 \quad 35-124$. 
692 Kelly, N., Metaxas, A., 2008. Diversity of invertebrate colonists on simple and complex substrates at 693 hydrothermal vents on the Juan de Fuca Ridge. Aquatic Biology 3, 271-281.

694

695 Kelly, N., Metaxas, A., Butterfield, D., 2007. Spatial and temporal patterns of colonization by deep696 sea hydrothermal vent invertebrates on the Juan de Fuca Ridge, NE Pacific. Aquatic Biology 1, 1-16.

697

698 Le Bris, N., Gaill, F., 2007. How does the annelid Alvinella pompejana deal with an extreme

699 hydrothermal environment? Reviews in Environmental Sciences and Biotechnology 2007 (6), $197-$ 700221.

701

702 Le Bris, N., Gaill, F., 2010. Microbial habitats associated with deep-sea hydrothermal vent 703 invertebrates: insights from microanalysis and geochemical modeling. In: Kiel, S. (Ed.), the Vent 704 and Seep Biota, pp. 51-71.

705

706 Le Bris, N., Govenar, B., Le Gall, C., Fisher, C.R., 2006. Variability of physico-chemical conditions 707 in 950'N EPR diffuse-flow vent habitats. Marine Chemistry 98, 167-182.

708

709 Le Bris, N., Zbinden, M., Gaill, F., 2005. Processes controlling the physico-chemical micro-

710 environments associated with Pompeii worms. Deep-Sea Research I 52, 1071-1083.

711

712 Levesque, C., Juniper, S.K., Limén, H., 2006. Spatial organization of food webs along habitat 713 gradients at deep sea hydrothermal vents on Axial volcano, Northeast pacific. Deep-Sea Research I $714 \quad 53,726-739$. 
716 Levesque, C., Juniper, S.K., Marcus, J., 2003. Food resource partitioning and competition among 717 Alvinellid polychaetes of Juan de Fuca Ridge hydrothermal vents. Marine Ecology Progress Series $718246,173-182$.

720 Levesque, C., Limén, H., Juniper, K., 2005. Origin, composition and nutritional quality of particulate 721 matter at deep-sea hydrothermal vents on Axial Volcano, NE Pacific. Marine Ecology Progress 722 Series 289, 43-52.

724 Limén, H., Stevens, C.J., Bourass, Z., Juniper, S.K., 2008. Trophic ecology of siphonostomatoid 725 copepods at deep-sea hydrothermal vents in the northeast Pacific. Marine Ecology Progress Series $726359,161-170$.

Limén, H., Levesque, C., Juniper, K., 2007. POM in macro-/meiofaunal food webs associated with three flow regimes at deep-sea hydrothermal vents on Axial Volcano, Juan de Fuca Ridge. Marine Biology 153, 129-139. Cary, S.C., 2001. Chemical speciation drives hydrothermal vent ecology. Nature 410, 813-816.

Lutz, R., Jablonski, D., RD, T., 1984. Larval dispersal at deep-sea hydrothermal vents. Science 226, $1451-1454$.

738 McCutchan, J.H., Lewis, W.M., Kendall, C., McGrath, C.C., 2003. Variation in trophic shift for 739 stable isotope ratios of carbon, nitogen, and sulfur. Oikos 102, 378-390. 
741 Minagawa, M., Wada, E., 1984. Stepwise enrichment of ${ }^{15} \mathrm{~N}$ along food chains: further evidence and 742 the relation between $\delta^{15} \mathrm{~N}$ and animal age. Geochimica and Cosmochimica Acta 48, 1135-1140.

743

744 Miyake, H., Kitada, M., Tsuchida, S., Okuyama, Y., Nakamura, K.-i., 2007. Ecological aspects of 745 hydrothermal vent animals in captivity at atmospheric pressure. Marine Ecology 28 (1), 86-92.

748 Mullineaux, L.S., Mills, S.W., Goldman, E., 1998. Recruitment variation during a pilot colonization 749 study of hydrothermal vents (950'N, East Pacific Rise). Deep-Sea Research II 45, 441-464. 750

751 Mullineaux, L.S., Peterson, C.H., Micheli, F., Mills, S.W., 2003. Successional mechanism varies 752 along a gradient in hydrothermal fluid flux at deep-sea vents. Ecological Monographs 73 (4), 523753542.

754

755 Nees, H.A., Lutz, R.A., Shank, T.M., Luther III, G.W., 2009. Pre- and post-eruption diffuse flow 756 variability among tubeworm habitats at 9 ${ }^{\circ} 50^{\prime}$ north on the East Pacific Rise. Deep-Sea Research II $757 \quad 56,1607-1615$.

758

759 Phillips, D.L., Gregg, J.W., 2003. Source partitioning using stable isotopes: coping with too many 760 sources. Oecologia 136, 261-269.

762 Phleger, C.F., Nelson, M.M., Groce, A.K., Cary, S.C., Coyne, K., Gibson, J.A.E., Nichols, P.D., 763 2005. Lipid biomarkers of deep-sea hydrothermal vent polychaetes-Alvinella pompejana, A. caudata, 764 Paralvinella grasslei and Hesiolyra bergii. Deep-Sea Research I 52, 2333-2352. 
766 Post, D.M., 2002. Using stable isotopes to estimate trophic position: models, methods, and 767 assumptions. Ecology 83 (3), 703-718.

768

769 Post, D.M., Layman, C.A., Arrington, D.A., Takimoto, G., Quattrochi, J., Montana, C.G., 2007.

770 Getting the fat of the matter: models, methods and assumptions for dealing with lipids in stable 771 isotope analyses. Oecologia 152, 179-189.

772

773 Pradillon, F., Zbinden, M., Le Bris, N., Hourdez, S., Barnay, A.-S., Gaill, F., 2009. Development of 774 assemblages associated with alvinellid colonies on the walls of high-temperature vents at the East 775 Pacific Rise. Deep-Sea Research II 56, 1622-1631.

776

777 Pradillon, F., Zbinden, M., Mullineaux, L.S., Gaill, F., 2005. Colonisation of newly-opened habitat 778 by a pioneer species, Alvinella pompejana (Polychaeta: Alvinellidae), at East Pacific Rise vent sites. Marine Ecology Progress Series 302, 147-157.

780

781 Sarrazin, J., Juniper, S.K., 1999. Biological characteristics of a hydrothermal edifice mosaic 782 community. Marine Ecology Progress Series 185, 1-19.

783

784 Sarrazin, J., Juniper, S.K., Massoth, G.J., Legendre, P., 1999. Physical and chemical factors 785 influencing species distributions on hydrothermal sulfide edifices of the Juan de Fuca Ridge, NE 786 pacific. Marine Ecology Progress Series 190, 89-112.

788 Shank, T., Fornari, D., Von Damm, K., Lilley, M., Haymon, R., Lutz, R., 1998. Temporal and spatial 789 patterns of biological community development at nascent deep-sea hydrothermal vents $\left(9^{\circ} 50^{\prime} \mathrm{N}\right.$, East 790 Pacific Rise). Deep-Sea Research II 45, 465-515. 
792 Sievert, S.M., Vetriani, C., 2012. Chemoautotrophy at Deep-Sea vents. Oceanography 25(1), 218-

793 233.

794

795 Sievert, S.M., Taylor, C.D., Schuster, S.C., Le Bris, N., Gulmann, L.K., Molyneaux, S.J., Richberg, 796 K.P., Sylva, S.P., Wuchter, C., 2009. An integrated approach to study chemolithoautotrophic 797 processes at deep-sea hydrothermal vents at $9^{\circ}$ N, East Pacific Rise. ASLO, NICE, p. 246.

798

799 Soule, S.A., Fornari, D.J., Perfit, M.R., Rubin, K.H., 2007. New insights into mid-ocean ridge 800 volcanic processes from the 2005-2006 eruption of the East Pacific Rise, 9 degrees 46 ' N-9 degrees 80156 ' N. Geology 35 (12), 1079-1082

802

803

Taylor, C., Wirsen, C., Gaill, F., 1999. Rapid microbial production of filamentous sulfur mats at 804 hydrothermal vents. Applied and Environmental Microbiology 65 (5), 2253-2255.

805

806 Tunnicliffe, V., 1991. The biology of hydrothermal vents: ecology and evolution. Oceanography and 807 Marine Biology Annual Review 29, 319-407.

808

809 Van Dover, C., Berg, C., Turner, R., 1988. Recruitment of marine invertebrates to hard substrates at 810 deep-sea hydrothermal vents on the East Pacific Rise and Galapagos spreading center. Deep-Sea 811 Research 35 (10/11), 1833-1849.

812

813 Van Dover, C.L., 2000. The ecology of Deep-Sea Hydrothermal Vents. Princeton University press, 814 424pp. 
816 Van Dover, C.L., Fry, B., 1989. Stable isotopic compositions of hydrothermal vent organisms.

817 Marine Biology 102, 257-263.

818

819 Van Dover, C.L., Fry, B., 1994. Microorganisms as food resources at Deep-Sea hydrothermal vents.

820 Limnology and Oceanography 39, 51-57.

821

822 Vereshchaka, A.L., Vinogradov, G.M., Lein, A.Y., Dalton, S., Dehairs, F., 2000. Carbon and

823 nitrogen isotopic composition of the fauna from the Broken Spur hydrothermal vent fields. .

824 Marine Biology 136, 11-17.

825

826 Zbinden, M., Le Bris, N., Compère, P., Martinez, I., Guyot, F., Gaill, F., 2003. Mineralogical

827 gradients associated with alvinellids at deep-sea hydrothermal vents. Deep-Sea Research I 50, 269-

828280.

829

830

831

832

833

834

835

836

837

838

839

840 
841 Table 1. Details of TRACs (Titanium Ring for Alvinellid Colonization) deployment and recovery at the EPR $9^{\circ} 50^{\prime} \mathrm{N}$ in 2006.

842 Mean temperature data with standard deviation ( \pm SD) were calculated according to the in situ temperature recording by

843 MICREL autonomous probes attached to TRACs.

\begin{tabular}{|c|c|c|c|c|c|c|}
\hline TRAC ID & $\begin{array}{l}\text { Localisation on } \\
\text { vent sulfide } \\
\text { edifice } \\
\end{array}$ & $\begin{array}{l}\text { Date of } \\
\text { deployment (dive } \\
\text { number) }\end{array}$ & $\begin{array}{l}\text { Date of } \\
\text { recovery } \\
\text { (dive number) }\end{array}$ & $\begin{array}{l}\text { Temperature range } \\
\left({ }^{\circ} \mathrm{C}\right)\end{array}$ & $\begin{array}{l}\text { Mean } \\
\text { temperature } \\
\left({ }^{\circ} \mathrm{C}\right) \\
\end{array}$ & $\begin{array}{l}\text { Bacterial mats present } \\
\text { during recovery (video } \\
\text { in situ observation) }\end{array}$ \\
\hline 4ALVT & Alvinella habitat & 4 Nov (4263) & 8 Nov (4267) & $2.1-21.7 *$ & $8.6 \pm 2.7 *$ & Yes \\
\hline 4TEVT & Tevnia habitat & 4 Nov (4263) & 8 Nov (4267) & 2.4-7.9 & $5.2 \pm 0.9$ & Yes (small patch) \\
\hline 4BAST & Bare basalt & 4 Nov (4263) & 8 Nov (4267) & $1.9-4.8$ & $2.4 \pm 0.4$ & No \\
\hline 13ALVT & Alvinella habitat & 17 Dec (4289) & 30 Dec (4292) & $\begin{array}{l}\text { Probe 1: } 66.8->175.7 \\
\text { Probe 2: } 10.6->243.1\end{array}$ & $\begin{array}{l}\text { n.c. } \\
58.3 \pm 26.3 * *\end{array}$ & Yes (everywhere) \\
\hline 13TEVT & Tevnia habitat & 17 Dec (4289) & $30 \mathrm{Dec}(4292)$ & $2.3-29$ & $10.5 \pm 4.9$ & Yes (few patches) \\
\hline 13BAST & Bare basalt & 17 Dec (4289) & 30 Dec (4292) & $1.9-2.5$ & $2.1 \pm 0.1$ & No \\
\hline 33ALVB & Alvinella habitat & 10 Nov (4269) & $13 \operatorname{Dec}(4285)$ & $\begin{array}{l}\text { Probe } 1: 1.9-14.8 \\
\text { Probe } 2: 1.9-18.7\end{array}$ & $\begin{array}{l}6.3 \pm 1.9 \\
8.7 \pm 2.4\end{array}$ & Yes (everywhere) \\
\hline 29TEVT & Tevnia habitat & 14 Nov (4273) & 13 Dec (4285) & $1.9-31$ & $5.3 \pm 3.2$ & Yes (few patches) \\
\hline
\end{tabular}

* Mean temperature and range are given for the 3 last days of the experiment, after the TRAC fell a few centimetres away from its original location.

$845 * *$ Mean temperature calculated from measurements obtained in the first week, before temperature became consistently higher than the probe accuracy

846 limit $\left(100^{\circ} \mathrm{C}\right)$

847 n.c.: not calculated. 
855 Table 2. Density of the dominant taxa in $\mathrm{dm}^{3}$ collected within the nine Titanium Ring for Alvinellid Colonization devices (TRACs) deployed

856 between November and December 2006 at the East Pacific Rise. TRACs are detailed in Table 1. Trophic guilds are after Bergquist et al. (2007):

$857 \mathrm{~B}=$ bacterivore $\mathrm{S}=$ scavenger/detritivore; $\mathrm{P}=$ predator; $\mathrm{d}=$ surface deposit-feeder or grazer, $\mathrm{s}=$ suspension feeder.

\begin{tabular}{|c|c|c|c|c|c|c|c|c|c|c|}
\hline \multirow[t]{2}{*}{ Taxonomic group } & \multirow{2}{*}{$\begin{array}{l}\text { Trophic } \\
\text { guild }\end{array}$} & \multicolumn{9}{|c|}{ Density of specimens per TRAC in $\mathrm{dm}^{3}$} \\
\hline & & 4ALVT & 4TEVT & 4BAST & 13ALVT & 13TEVT & 13BAST & $33 \mathrm{ALVB}$ & 29TEVT & 29BAST \\
\hline Alvinella pompejana & $\mathrm{B}(\mathrm{d}, \mathrm{s})$ & 14 & - & - & 20 & - & - & 7 & - & - \\
\hline Branchinotogluma sandersi & $\mathrm{P}$ & - & 1 & - & - & 1 & - & - & 1 & - \\
\hline Lepidonotopodium riftense & $\mathrm{P}$ & - & 2 & - & - & 1 & 1 & - & 4 & - \\
\hline Branchinotogluma hessleri & $\mathrm{P}$ & - & - & - & - & 2 & - & 2 & - & - \\
\hline Lepetodrilus elevatus & $\mathrm{B}(\mathrm{d}, \mathrm{s})$ & - & 143 & 18 & 4 & 1094 & 1 & 62 & 688 & 4 \\
\hline Dirivultid copepods & $\mathrm{B}(\mathrm{d})$ & 565 & 113 & 47 & 327 & 86 & 9 & - & - & - \\
\hline Ventiella sulfuris & $\mathrm{B}$ & - & 1 & 6 & 160 & 223 & - & 183 & 125 & 4 \\
\hline Total density per TRAC & & 581 & 286 & 71 & 517 & 1429 & 71 & 257 & 834 & 29 \\
\hline
\end{tabular}


858 Table 3. Trophic position (TP) calculated following Post (2002) by using $\delta^{15} \mathrm{~N}$ of episymbionts as trophic baseline and trophic fractionation of

859 1.4\%o (invertebrate's diet) and 3.3\%o (microbial diet) (Bergquist et al., 2007). Species are those used for stable isotopes recovered from Titanium

860 Ring for Alvinellid Colonization devices (TRACs) deployed in both Alvinella pompejana and Tevnia jerichonana habitats. TRACs are detailed

861 in Table 1. Feeding guilds according to this study are in brackets and as follow: B for bacterivore, D for detritivore and P for predator.

862

863

\begin{tabular}{ccccccc}
\hline Taxonomic group & 4ALVT & 13ALVT & 33ALVB & 4TEVT & 13TEVT & 29TEVT \\
\hline $\begin{array}{c}\text { Trophic baseline } \\
\text { Episymbionts (prokariotes) }\end{array}$ & 1.0 & 1.0 & 1.0 & - & - & - \\
Microbial diets and detritus & & & & & & \\
$\quad$ Alvinella pompejana & $1.4(\mathrm{~B})$ & $1.4(\mathrm{~B})$ & $1.6(\mathrm{~B})$ & - & - & - \\
$\quad \begin{array}{c}\text { Dirivultid copepods } \\
\text { Lepetodrilus elevatus }\end{array}$ & $1.7(\mathrm{~B})$ & $1.6(\mathrm{~B})$ & - & $0.8(\mathrm{~B})$ & $1.6(\mathrm{~B})$ & - \\
$\quad-$ & - & $2.1(\mathrm{D})$ & $2.1(\mathrm{D})$ & $1.9(\mathrm{~B})$ & $2.0(\mathrm{D})$ \\
$\quad$ Ventiella sulfuris & - & $2.0(\mathrm{D})$ & $2.1(\mathrm{D})$ & - & $2.0(\mathrm{D})$ & $2.1(\mathrm{D})$ \\
Invertebrate diets & - & - & - & $2.9(\mathrm{D})$ & $4.1(\mathrm{P})$ & $6.2(\mathrm{P})$ \\
Branchinotogluma sandersi & - & - & - & $5.2(\mathrm{P})$ & $3.9(\mathrm{P})$ & $2.2(\mathrm{D})$ \\
Lepidonotopodium riftense \\
Branchinotogluma hessleri
\end{tabular}

864 
870 Table 4. Summary of ranges of stable carbon $\left(\delta^{13} \mathrm{C}\right)$ and nitrogen $\left(\delta^{15} \mathrm{~N}\right)$ isotopic ratios of similar invertebrates issued from the literature and

871 those targeted in this present study. EPR: East Pacific Rise. JdF: Juan de Fuca. HCl means that samples were acidifed. In this study, values of

$872 \delta^{13} \mathrm{C}$ and $\delta^{15} \mathrm{~N}$ are the average and standard deviation ( \pm SD) of the values measured for a given taxa recovered for any of the 6 colonization

873 experiments.

\begin{tabular}{|c|c|c|c|c|c|c|c|}
\hline Sources & Species & Location & Fixation & $\mathrm{HCl}$ & Storage & $\delta^{13} \mathrm{C}(\%)$ & $\delta^{15} \mathrm{~N}(\%)$ \\
\hline This study & Alvinella pompejana & EPR $9^{\circ} 50^{\prime} \mathrm{N}$ & Formaldehyde & no & Ethanol & $-11.4 \pm 0.8$ & $6.5 \pm 0.6$ \\
\hline Van Dover and Fry, 1989 & Lepetodrilus sp. & EPR $21^{\circ} \mathrm{N}$ & Freezing & yes & - & -12 & 9.2 \\
\hline This study & Lepetodrilus elevatus & EPR $9^{\circ} 50^{\prime} \mathrm{N}$ & Formaldehyde & no & Ethanol & $-13.3 \pm 1.4$ & $8.4 \pm 0.2$ \\
\hline Van Dover and Fry, 1989 & Lepidonotopodium riftense & EPR $21^{\circ} \mathrm{N}$ & Freezing & yes & - & -11.6 & 8.1 \\
\hline This study & Lepidonotopodium riftense & EPR 9०50’N & Formaldehyde & no & Ethanol & $-15.5 \pm 0.3$ & $8.9 \pm 2.0$ \\
\hline Bergquist et al., 2007 & Branchinotogluma sandersi & $\mathrm{JdF}$ & Formaldehyde & yes & Ethanol & $-20.1 /-16.1$ & $4.4 / 5.8$ \\
\hline This study & Branchinotogluma sandersi & EPR: $9^{\circ} 50^{\prime} \mathrm{N}$ & Formaldehyde & no & Ethanol & $-11.5 \pm 0.9$ & $9.8 \pm 2.4$ \\
\hline Colaço et al., 2002 & Amphipods & Menez Gwen & Freezing & yes & - & -21.6 & $1.8 \pm 0.62$ \\
\hline Fisher et al., 1994 & Ventiella sulfuris & Galapagos & Freezing & yes & - & -24.1 & 2.3 \\
\hline This study & Ventiella sulfuris & EPR $9^{\circ} 50^{\prime} \mathrm{N}$ & Formaldehyde & no & Ethanol & $-13.3 \pm 0.3$ & $8.5 \pm 0.1$ \\
\hline Limén et al., 2007 & $\begin{array}{c}\text { Aphotopontius forcipatus } \\
\text { Stygiopontius }\end{array}$ & $\mathrm{JdF}$ & Freezing & yes & - & $-22.2 /-13.5$ & 4.7 \\
\hline
\end{tabular}


875

876

877

878

879

880

881

882

883

884

885

886

887

888

889

890

891

892

893

894

895

896

897

898

899

Figure captions

Fig. 1. Map of location of Titanium Ring for Alvinellid Colonization (TRAC) experiments. Right:

East Pacific Rise showing Mexico City (*); left: detailed map of the $9^{\circ} 50^{\prime} \mathrm{N}$ segment.

Fig. 2. Deployment location of Titanium Ring for Alvinellid Colonization devices (TRACs) on the TICA site. (A) TRAC (red arrow) deployed on Alvinella pompejana habitat (green asterisk). (B)

TRAC (red arrow) deployed on Tevnia jerichonana habitat (blue circle). (C) TRAC (red arrow) deployed directly on fresh bare basalt. The dark line represents the outline of the sulfide edifice viewed laterally. The scale bars represent 1 metre.

Fig. 3. Semi-continuous temperature measurements during in situ deployment of TRACs (Titanium Ring for Alvinellid Colonization). A) Deployments (depl.) on fresh bare basalt. B) Deployments (depl.) at the base of Tevnia jerichononana tubeworms. C) Deployments (depl.) on alvinellids, where for the 13-day and 33-day deployments, two MICREL probes where attached to TRACs giving two temperature records in black and grey colours. The arrow in the 4-day deployment indicates when the TRAC moved from its original position. Please note that temperatures higher than $100^{\circ} \mathrm{C}$ (probe accuracy limit) in the 13-day deployment should be taken with caution.

Fig. 4. $\delta^{13} \mathrm{C}$ and $\delta^{15} \mathrm{~N}$ values of dominant taxa in the Titanium Ring for Alvinellid Colonization (TRACs) (A) in the Alvinella pompejana habitat and (B) in the Tevnia jerichonana habitat. Numbers within symbols represent the number of days in situ of TRAC deployments from which the taxa was recovered. Dashed grey boxes represent the two other potential primary producers where $\delta^{13} \mathrm{C}$ and $\delta^{15} \mathrm{~N}$ for particle organic matter (POM) was taken from the diffuse flow of a vent at Juan de Fuca Ridge (Limén et al., 2007), in (A) originating from the communities of Paralvinella sp. that live close to the vent openings: $\delta^{13} \mathrm{C}=-16.7$ to $-17.2 \%$ and $\delta^{15} \mathrm{~N}=4.6$ to $6.6 \%$, in (B) originating from 
900 an intermediate habitat of a sulfide edifice: $\delta^{13} \mathrm{C}=-18.3$ to $-19.3 \%$ and $\delta^{15} \mathrm{~N}=4.6$ to $7.4 \%$. In (A) 901 and (B) Chemoautotrophic Bacteria (Chemo. Bact.) are from Campbell et al. (2003) where $\delta 13 \mathrm{C}=-$ $90212 \%$ and $-8 \%$ and, $\delta^{15} \mathrm{~N}=0-4 \%$. Error bars are standard deviations of the mean; $n=5$ for $A$.

903 pompejana; pools of 3 specimens for Lepidonotopodium riftense and for Branchinotogluma

904 hessleri; pools of 2 specimens for Branchinotogluma sandersi, pools of 20 specimens for 905 Lepetodrilus elevatus and for Ventiella sulfuris and pools of 100 specimens for the dirivultid 906 copepods.

907

908 Fig. 5. Synthesized food web for community recovered within Titanium Ring for Alvinellid 909 Colonization (TRAC) at the TICA site in November and December 2006 based on Bergquist et al. 910 (2007) and Govenar (2012) but modified according to this study. Trophic guilds are those calculated 911 from Table 3. Arrows indicate direct consumption. 


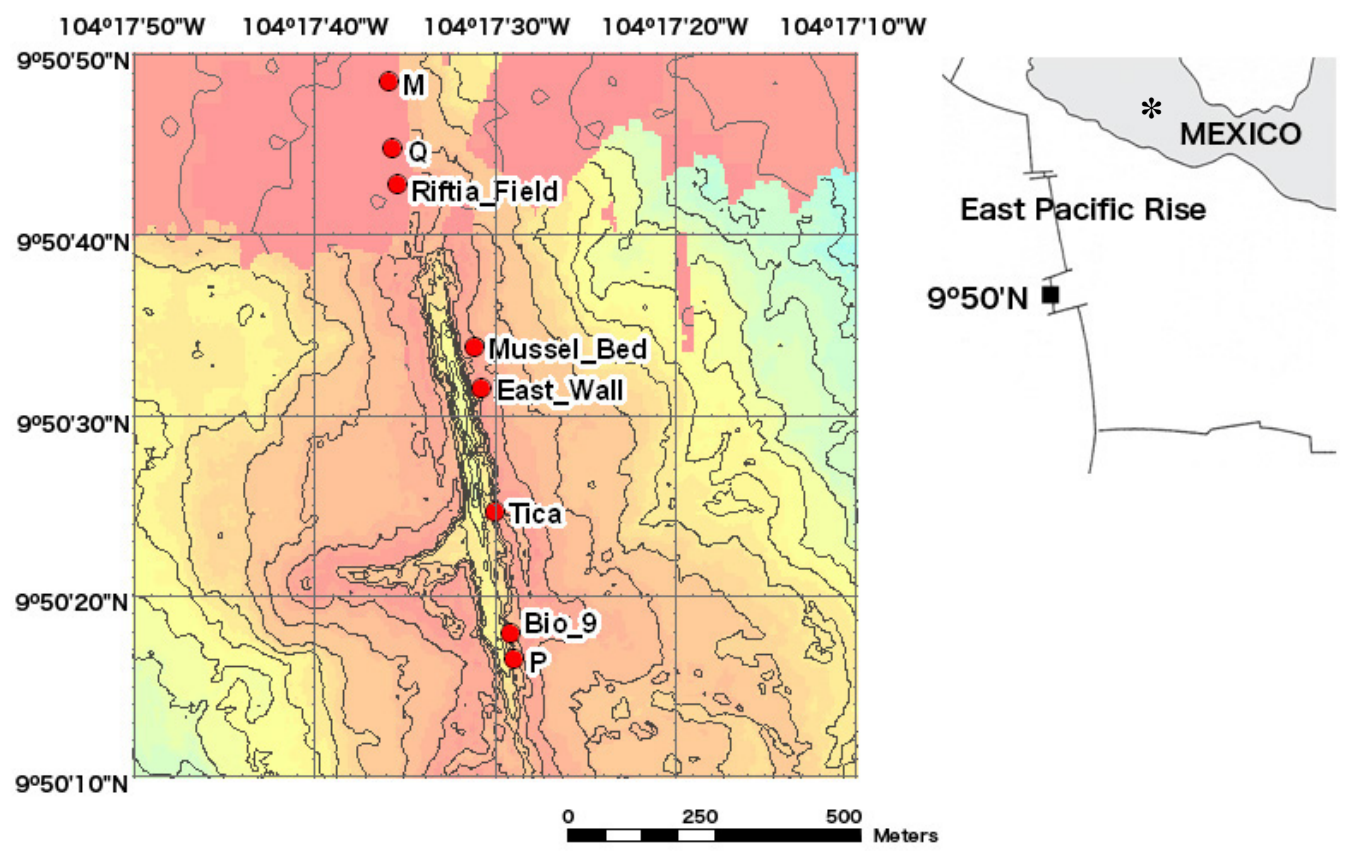




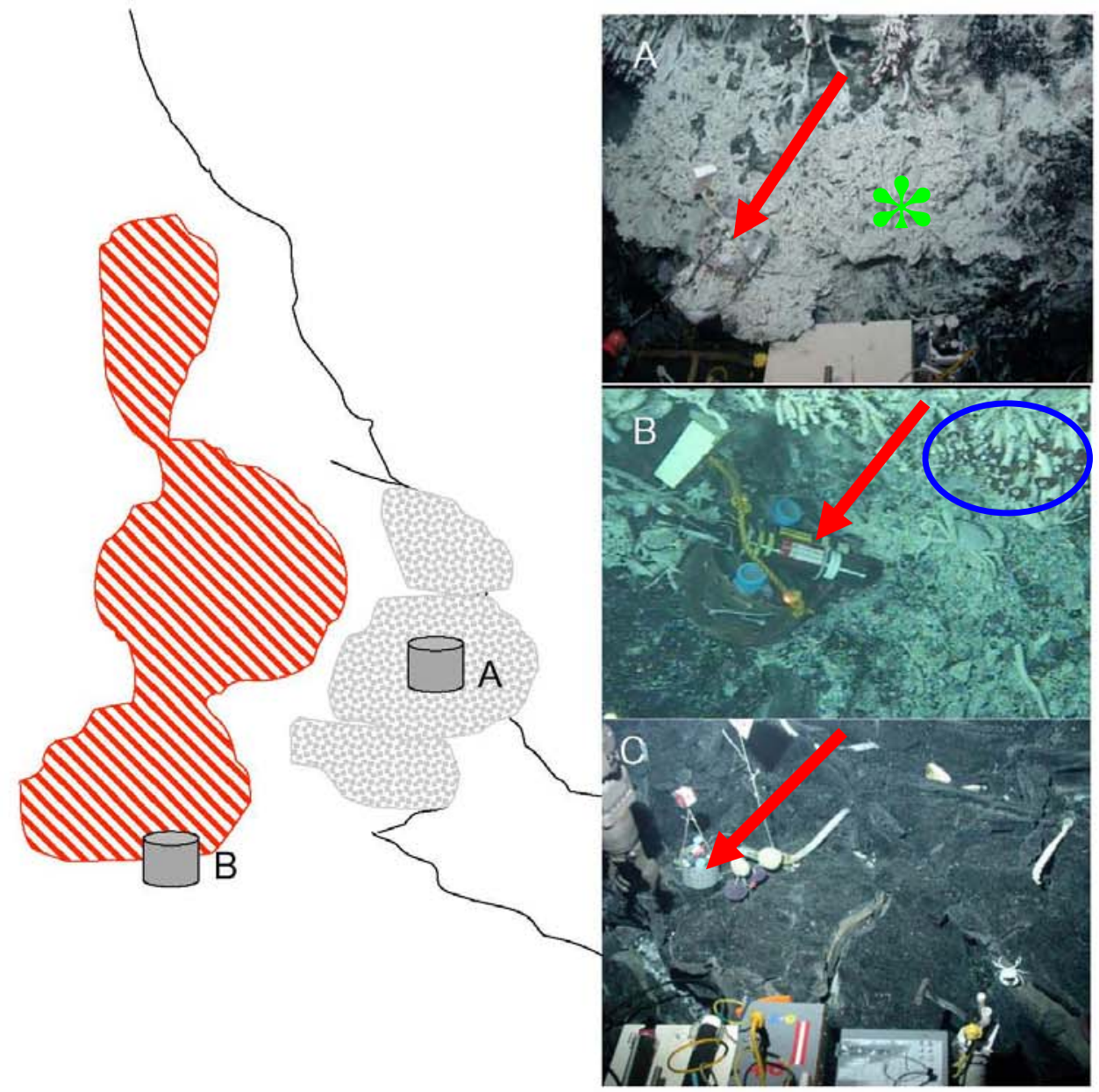

A. Alvinella pompejana habitat (4ALVT, 13ALVT)

B. Tevnia jerichonana habitat (4TEVT, 13TEVT, 29TEVT)

C. Bare basalt habitat

(4BAST, 13BAST, 29BAST) 
A) Basalt

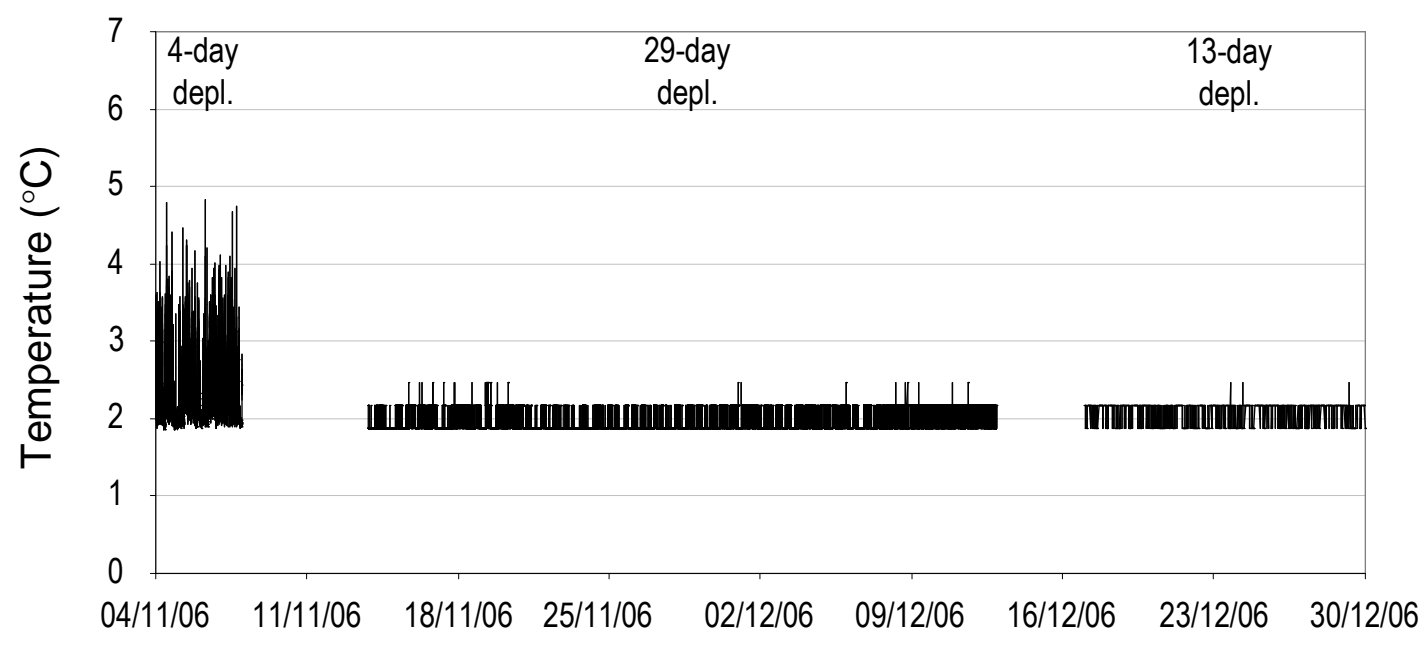

B) Tevnia

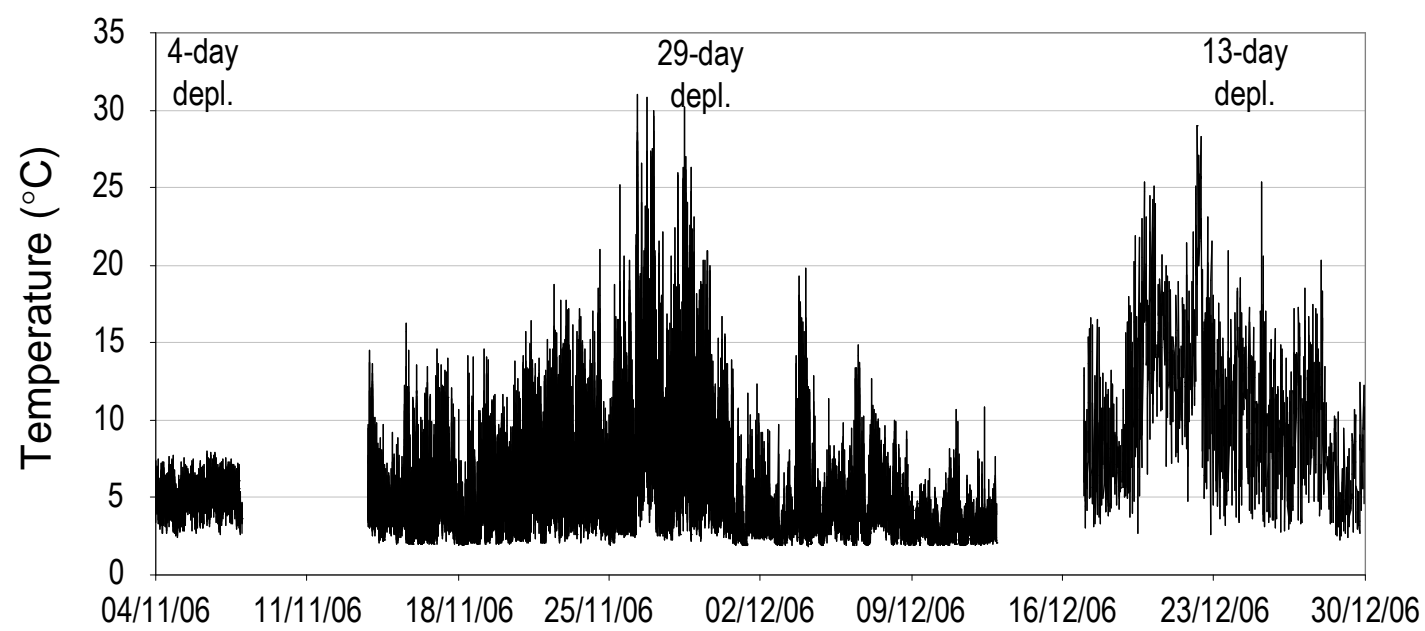

C) Alvinellids

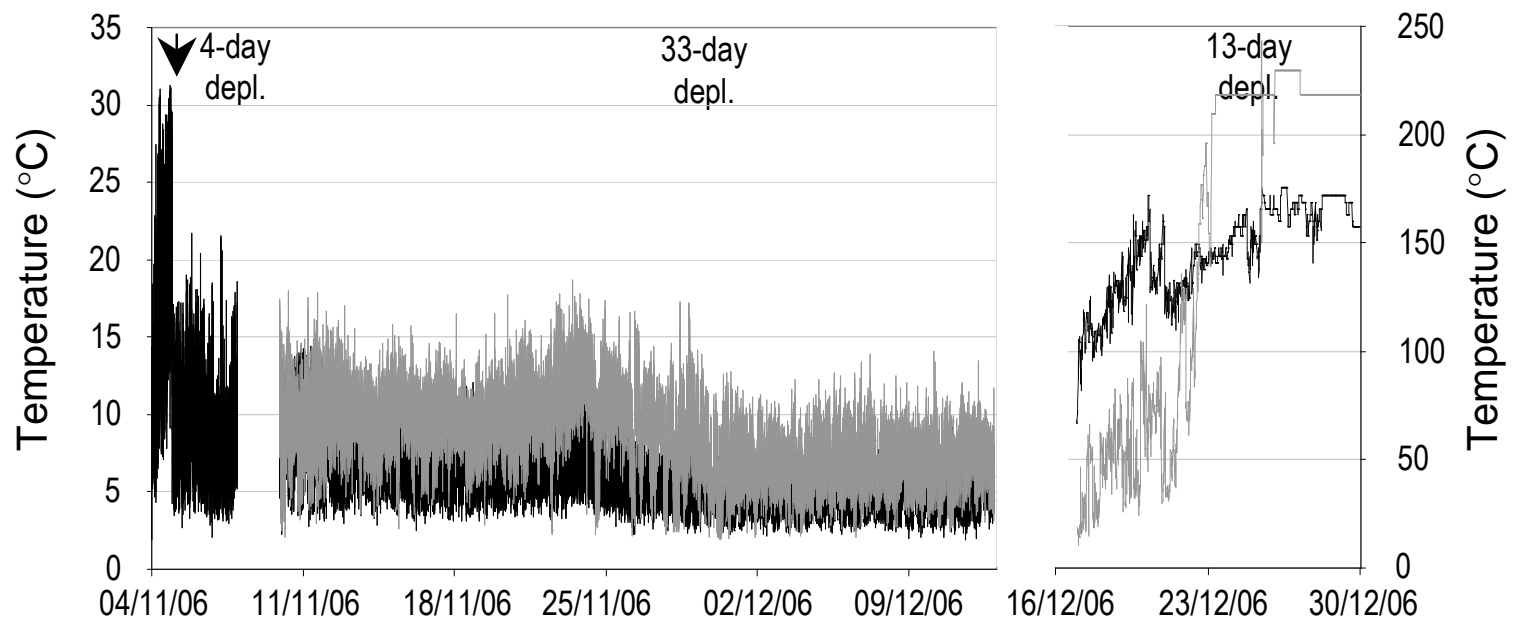

Date 


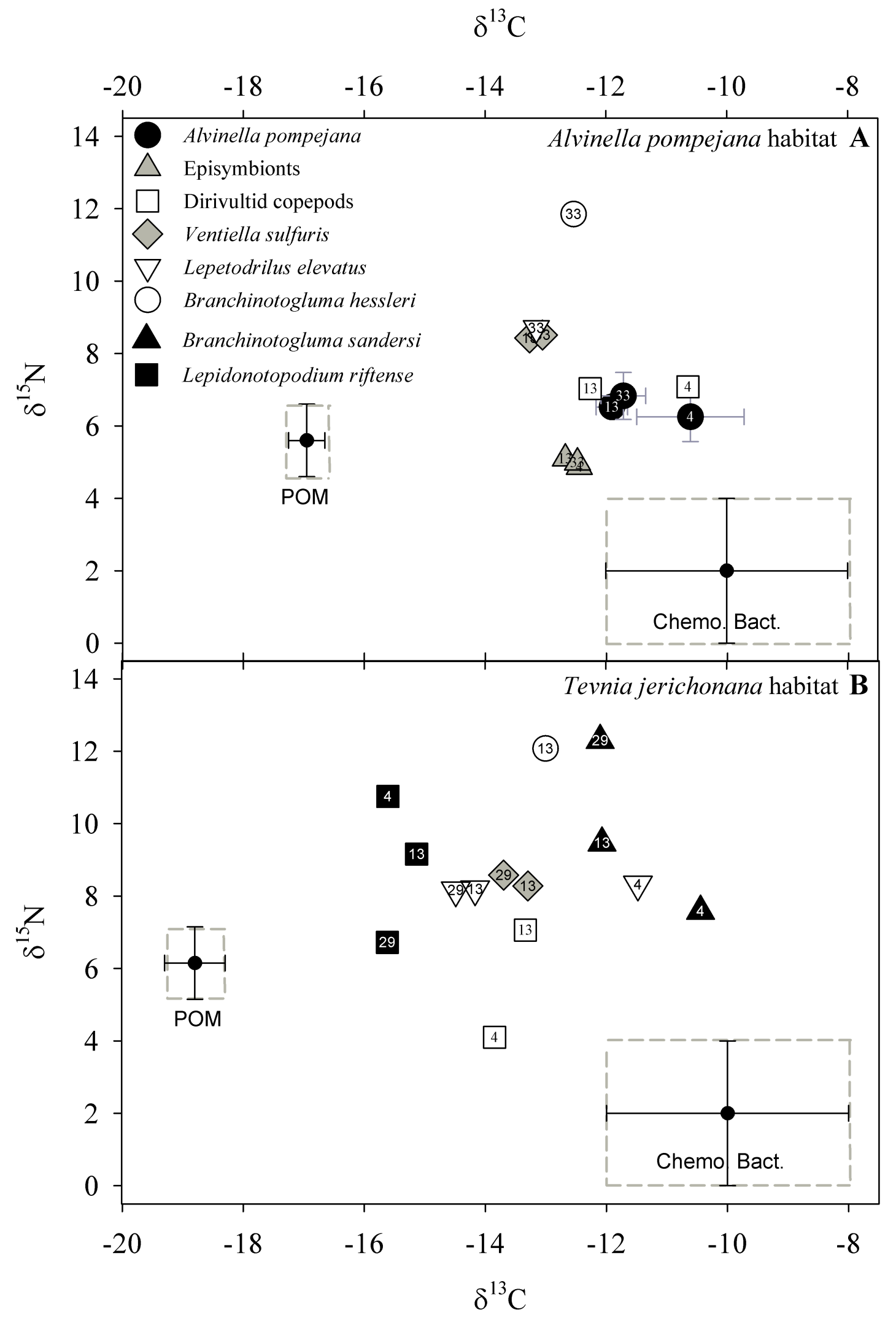




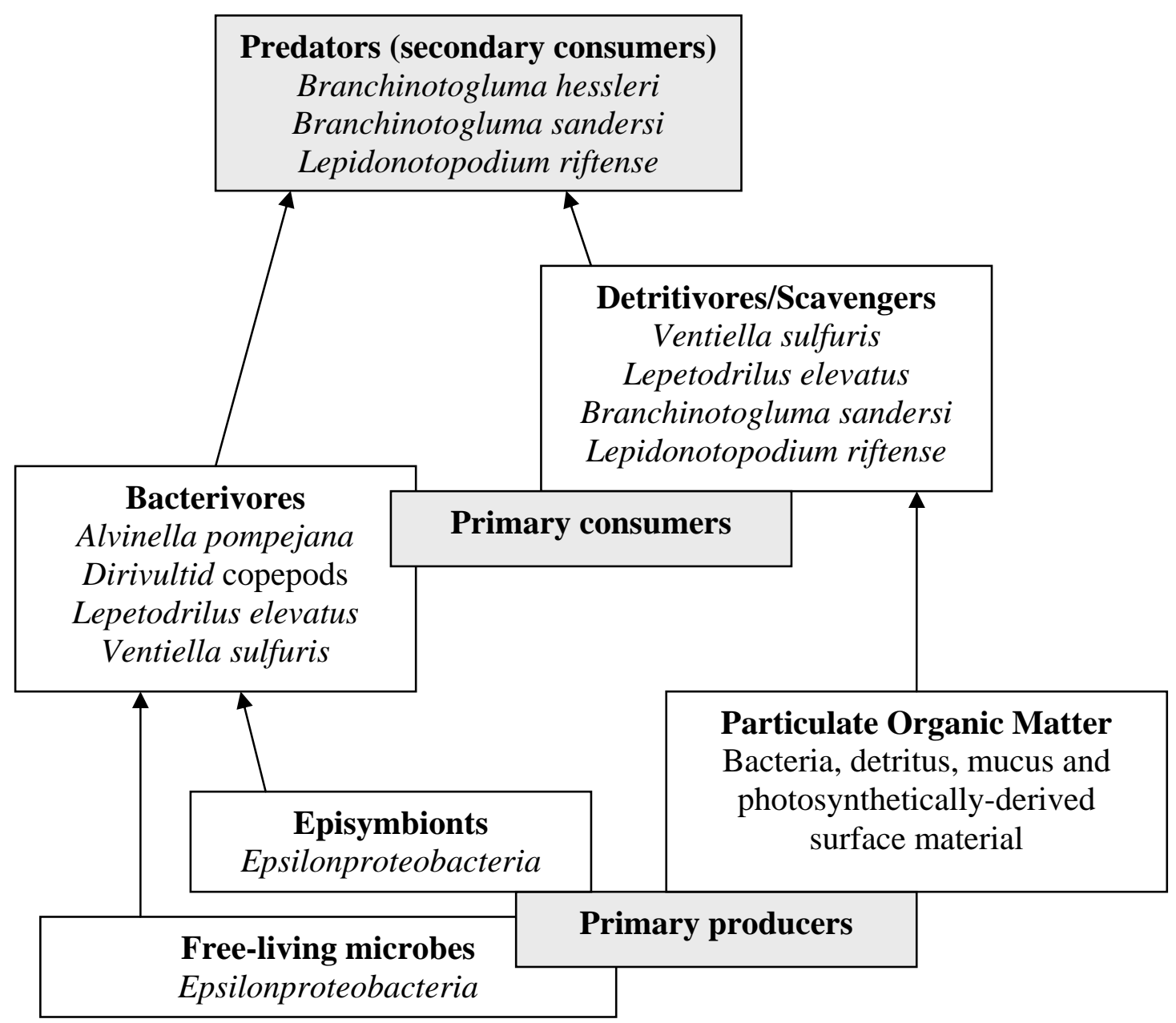

